\title{
"In the days of my life." Elite activity and interactions in the Maya lowlands from Classic to Early Postclassic times (the long ninth century, AD 760-920)
}

"En el curso de mi vida". Acciones e interacciones de las elites en las tierras bajas mayas del Clásico al Posclásico temprano (el largo siglo IX, 760-920 d.C.) "De mon vivant ". Actions et interactions des élites dans les basses terres mayas du Classique au Postclassique ancien (le long IXe siècle, 760-920 apr. J.-C.)

\section{(2) OpenEdition}

\section{Journals}

Édition électronique

URL : http://journals.openedition.org/jsa/15362

DOI : 10.4000/jsa. 15362

ISSN : 1957-7842

Éditeur

Société des américanistes

Référence électronique

" "In the days of my life." Elite activity and interactions in the Maya lowlands from Classic to Early Postclassic times (the long ninth century, AD 760-920) », Journal de la société des américanistes [En ligne], Maya times | 2017, mis en ligne le 10 mai 2019, consulté le 10 mai 2019. URL : http:// journals.openedition.org/jsa/15362 ; DOI : 10.4000/jsa.15362 


\title{
"In the days of my life." Elite activity and interactions in the Maya lowlands from Classic to Early Postclassic times (the long ninth century, AD 760-920)
}

\author{
Marie Charlotte Arnauld*, Chloé Andrieu** \\ and Mélanie FORNÉ***
}

\begin{abstract}
As work continues on the archaeological and paleoenvironmental evidence relating to the end of the Classic period in the Maya Lowlands (traditionally dated AD 950), it appears that this "end" lasted too long - from 760 to $950-1050$ - to qualify as a brutal collapse. Certainly punctuated here and there by radical crises and ruptures, the temporal "transition" from the Classic to the Postclassic periods must be studied as a long and thick, or complex sequence that linked up different processes in different regions with a different time sequence (Demarest et al. 2004b). But it also activated generations of actors who came into play as they became conscious of, reacted, and adapted to those changes. Although hardly appropriate, the degree of chronological resolution reached by Maya Lowland archaeology allows us to tentatively evaluate the Terminal Classic sequence using the generational time span. We aim to identify actions and strategies developed in those cities using welldated archaeological sequences, and possibly envision how the calendric games stimulated an anticipation of political change. [Key words: Maya area, Terminal Classic, generation, transition, action, anticipation.]
\end{abstract}

"En el curso de mi vida”. Acciones e interacciones de las elites en las tierras bajas mayas del Clásico al Posclásico temprano (el largo siglo IX, 760-920 d.C.). Profundizando el conocimiento tanto arqueológico como paleoambiental del fínal del Clásico Terminal en las tierras bajas mayas -tradicionalmente fechado en 950 d.C.-, este "fin" parece demasiado dilatado - entre 760 y 950-1050- para que pueda calificarse de "colapso brutal". Sin duda alguna marcada en varios lugares por crisis y rupturas radicales, la "transición" temporal entre Clásico y Posclásico se debe de estudiar en sí misma como una secuencia larga y espesa, o compleja, que dio lugar a procesos más o menos rápidos, diferentes según las regiones (Demarest et al. 2004b). Pero también dicha secuencia temporal fomentó la acción de generaciones de actores conscientes de estos cambios, quienes reaccionaron y se adaptaron a dichos cambios. Aunque apenas suficiente, el grado de resolución cronológica

* CNRS, Archéologie des Amériques, 21 allée de l’Université, 92023 Nanterre Cedex [Marie-Charlotte.arnauld@cnrs.fr]; ** CNRS, Archéologie des Amériques, 21 allée de l'Université, 92023 Nanterre Cedex [andrieuchloe@gmail.com]; *** Archéologie des Amériques, 21 allée de l'Université, 92023 Nanterre Cedex [melanie.forne@gmail.com]. 
alcanzado por la arqueología de las tierras bajas mayas permite evaluar la secuencia del Clásico terminal al paso de las generaciones. Se intenta detectar acciones y estrategias desarrolladas en ciertas ciudades con secuencias bien fechadas, quizás aún vislumbrar anticipaciones del cambio político que la atención al juego de los calendarios sin duda habría estimulado. [Palabras claves: Area maya, Clásico Terminal, generación, transición, acción, anticipación.]

«De mon vivant ». Actions et interactions des élites dans les basses terres mayas du Classique au Postclassique ancien (le long IX $x^{\mathrm{e}}$ siècle, 760-920 apr. J.-C.). Au fur et à mesure que l'on approfondit les connaissances tant archéologiques que paléoenvironnementales sur la fin de la période classique dans les basses terres mayas - traditionnellement datée autour de 950 apr. J.-C. - , il apparaît que cette « fin » a duré trop longtemps - entre 760 et 950-1050 - pour être qualifiée d'effondrement brutal. Certes ponctuée ici et là de crises et de ruptures radicales, la " transition » temporelle du Classique au Postclassique doit être étudiée en elle-même comme une séquence longue et épaisse, ou complexe, ayant enchaîné plus ou moins rapidement des processus différents région par région (Demarest et al. 2004). Mais aussi, cette séquence temporelle a mis en jeu des générations d'acteurs qui ont pris conscience de ces changements, y ont réagi et s'y sont adaptés. Bien qu'à peine suffisant, le degré de résolution chronologique atteint dans l'archéologie des basses terres permet de tenter d'évaluer la séquence à l'aune des générations, ce qui autorise le repérage des actions et stratégies mises en place dans certaines cités aux séquences bien datées, voire permet d'envisager les anticipations du changement politique que l'attention portée au jeu des calendriers a certainement suscitées. [Mots-clés : Aire maya, Classique Terminal, générations, transition, action, anticipation.]

\section{Introduction}

Recent archaeological and environmental data on the end of the Classic period in the Maya Lowlands, show that it was both a brutal collapse in some regions and a long (between AD 760 and 1000) transition to Postclassic times in most regions. The so called Terminal Classic period can now be considered as a long temporal sequence entailing different processes in each region (Aimers 2007; Demarest et al. 2004a), with even two waves of political collapse in the northern regions (Hoggarth et al. 2015). Similar or analogous non-concomitant double waves might have also occurred in the southern lowlands. Before furthering the research on causalities, it is urgent to work out the chronological sequence of processes and waves with sufficient resolution and precision to enable us to correlate cultural and climatic changes. In order to improve chronological precision, this paper is a call for urgent, and if possible, collaborative research to assemble absolute datings, region by region, for phenomena such as cessation of monumental construction and resident occupation in investigated sites. More robustly than just hieroglyphic "terminal dates" in inscriptions (see Ebert 
"In the days of my life." Elite activity and interactions in the Maya lowlands

et al. 2014), those two markers help refine the timing of political collapses, including those regions that lack inscriptions.

But in order to achieve cultural/environmental correlations, we also need higher resolution referring to time intervals shorter than traditional one-to-two hundred yearlong ceramic phases. All over the lowlands, several generations of Maya agents perceived at least some of the diverse political and environmental changes, reacted and adapted to them. The adoption by archaeologists of the generation as a time unit, entails a deep shift in our approach of the past as divided by breaks (visible in material culture) opening/ending chrono-cultural phases. The shift means taking into account that the perception of risk or vulnerability, but also of novel opportunities, was important in people's decision-making and strategies of action, region by region, or center by center (Middleton 2012, p. 264, 265; Schollmeyer 2011, p. 412). The outcome was unknown to them, or the knowledge they had of "the end" differed widely from the one we now have. Despite the fact that much still needs to be done to fine-tune the many available site sequences, in this paper we attempt to reevaluate the Terminal Classic period using the time scale of 50 years, two human generations, and reorganize the evidence for a large body of sites (Figure 1) from AD 760 to 920 . We have done this with the aim of focusing on the actions and strategies implemented by each polity over decades of change. Traditionally, changes in several parameters of material culture are synchronized to build cultural sequences (although ceramics most often dominate). We tackle the Terminal Classic datasets as exhaustively as possible, under the premise that relationships among events and processes documented by archaeology and epigraphy can and must be reassessed through the temporal distance of 50 years, even though some of those relationships may have required longer or shorter time spans. In other words, priority is given to the time span in which past individuals perceived and memorized events "in the days of their life" and that of their parents, and became conscious of current events and unfolding processes.

We do not mean to imply that this shift will produce the definitive sequence for the Terminal Classic period (e.g. AD 760 and 920 are not to be taken as the limit of the Terminal Classic period). Rather, our ambition is to reevaluate the period in order to call for precision in the chronology of processes that are all too often considered secondary in the Maya collapse, such as elite action, mainly

1. "Most of the residences in the city are empty and they are falling into ruins. Fertile farms and beautiful estates are for sale but there is no one to buy them. Formerly the city of Suzhou was prosperous and its people tended to be extravagant. It is natural that after a period of prosperity a period of depression should follow; but I never dreamed that I should have to witness these misfortunes in the days of my life" (emphasis is ours). This citation from the diary of Ye Shaoyuan writing in Southern China in 1642, during the 1635-1650 crisis, painfully expresses the economic cycle acceleration, in this case linked to the collapse of the Ming dynasty (cited in Marmé 2008). 
elite political interaction (including conflicts), as well as commoners' action, that is to say, mainly movements, both seen through variation in monumental construction (including stela and altar erection) and residential occupation. Two caveats must be stressed. First, elite action is much better documented through architecture, iconography and epigraphy than presence/absence and movement of "commoners" (Lohse and Valdez 2004) through settlement archaeology and demography. Our study illustrates this shortcoming and we must insist on the fact that datasets about commoner presence or absence in most sites are poorly dated. Second, as noted by readers of our early draft, our chronological option is developed to the detriment of the spatial diversity of lowland histories. There is no doubt that the narrative format emphasizes the time dimension and that our research effort is structured by the current concern about chronologies (see Cowgill 2015, among others) as much as by the broader approach of the recent Mesures et textures du temps chez les Mayas colloquium in which it was presented.

Terminal Classic change was not uniform through the lowlands; it differed according to environments and polities and was not synchronous (see A. F. Chase et al. 2014). In the present study (see Figure 1 for regional subdivisions), we treat spatial diversity as much as possible, although certainly not in a way that will satisfy every Mayanist.

While acknowledging regional diversity, we must also remind the reader that elite interaction was strong across the lowlands through the Classic, and intensified during the Terminal Classic, which is, indeed, what we are attempting to validate. It may have been that Late Classic Maya elites endeavored to overcome the all-too-obvious balkanization process advancing through the lowlands, by searching for some level of general agreement and collective action. We must stress that by the late ninth century, Chichen Itza and Uxmal were showing trends towards (conscious) ideological, political and military unification. Also, considering the marked "mesoamericanization" of Maya Terminal Classic elites, it is relevant to envision elite interaction and strategies on a broad scale. Moreover, population movements - trade mobility as much as true migrations - are now recognized as having been intense during the Classic (e.g. Cucina 2015; Freiwald 2011, 2013; Price et al. 2014; Wright 2012), which certainly did not cancel out regional diversity, but at least created a pan-lowland system of critical importance during the late crises (Webster 2002, p. 207-208). It should be acknowledged that estimating the timing of political collapses on the basis of terminal hieroglyphic dates (Ebert et al. 2014) pays little attention to the plausible variation in political significance of monument erection from site to site and region to region, not to mention the absence of such practices in some important places like Palenque or the Northern Belize sites (Hoggarth et al. 2015, p. 322). Indeed, diversity as seen through epigraphic (Jackson 2005, 2013; Bey 2006), environmental (A. F. Chase et al. 2014; Douglas et al. 2015; 
"In the days of my life." Elite activity and interactions in the Maya lowlands

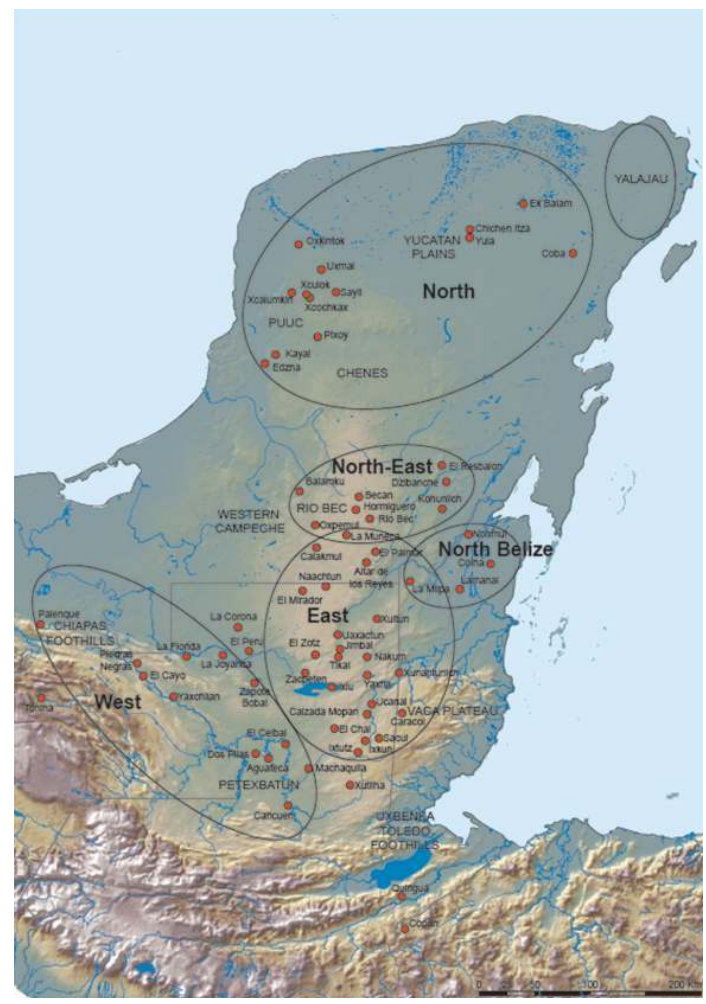

Fig. 1 - Map of the Maya Lowlands area showing the location of the archaeological sites mentioned in the text. The oval lines define the main regions, labeled "North", "North-East", "North Belize", "East" and "West". Their definition is partly based on the results of the time-space, political analysis by Ebert et al. (2014, fig. 5), but also on the presence/absence, nature, and epigraphic-iconographic content of carved monuments (Bíró 2012; Jackson 2005, 2013). The capital names roughly correspond with those of the 10 environmental and cultural zones recently defined by A.F. Chase et al. (2014, fig. 2.2): from north to south, "Yalajau" (inland freshwater wetlands; high annual rainfall $2000 \mathrm{~mm}$ ); "Chichen Itza and Yucatan plains" (cenotes, dry depressions, and fertile soils, low rainfall); "Puuc" (hilly zone with deep water table and fertile soils); "Calakmul and Western Campeche" (coastal swamps, karstic interior with seasonal swamps, or bajos); "Tikal" (center of "East", karstic with lakes, rivers and bajos); "Northern Belize" (karstic terraces crossed by rivers); the "Vaca Plateau" (karstic, high rainfall above $2000 \mathrm{~mm}$ ); "Palenque and Chiapas foothills" (varied ecosystems); "Seibal and Pasión" (or Petexbatun, streams and lakes); "Uxbenka and Toledo Foothills" (uplands with good soils and high rainfall). Most lowland zones receive from 700 to $1800 \mathrm{~mm}$ annual rainfall. (Map drawn by Jean-François Cuenot, ArchAm, based on the Electronic Atlas of Ancient Maya Sites, www.mayagis.smv.org). 
Dunning et al. 2012) and trade route evidence (Turner and Sabloff 2012) defines distinct regional divisions that do not overlap among themselves. Nevertheless, they may all have been determinants during these troubled periods. Rough epigraphic and environmental definitions of regions are used in this chronological approach, along with the proximate (decaying) hegemonies of Tikal, Calakmul, Caracol, and others large centers.

The first part of the paper provides a sociological framework to the compiled events and processes of the ninth century, since it briefly explores the sociopolitical transformation apparent in many Terminal Classic sites. We suggest that, in some regions at least, the weakening of sacred kingship institutions went together with the emergence of the large social groupings that prefigure the Postclassic sociopolitical entities. The second part outlines the research variables, specifies the focus on activity types, and evaluates difficulties in time resolution. The third, fourth and fifth sections briefly summarize the available evidence in the fifty-year format, which is cautiously applied with overlapping boundaries, from $\mathrm{AD} 760 / 780$ to $810 / 830,810 / 830$ to $850 / 870$, and $850 / 870$ to $900 / 920$. The final discussion raises a number of questions about the effect of generational periodization on our understanding of Terminal Classic changes.

\section{Politically and economically powerful houses in Maya Terminal Classic societies}

Whereas in the Classic-to-Postclassic transition much attention is currently paid to the collapse of the sacred kingship institution (or k'uhul ajaw authority), the repeated droughts, and the abandonment of urban settlements, a farreaching, albeit much less investigated process was probably going on: what can be called the autonomization of sub-royal elites (Chase 1992; Demarest et al. 2014; Graham 2006; Masson 2002, p. 20-21; McAnany 2013; Rathje 1970; Rice 1987). Of course, the Classic elites did not represent a uniform entity during the Classic period (Jackson 2005, 2013), and the strategies they followed to gain power from the ruling dynasties vary enormously from region to region. However, as most of these strategies required labor and war parties to support their endeavors (e.g. Graham 2006, p. 114), we suggest that, from roughly AD 700 to 1000 in a plurisecular process, intermediate social groups were generally accruing their political, economic, and probably military powers by integrating a certain proportion of Maya urban populations and by successfully attracting commoners. The result was the formation of what would become the later Postclassic groups, the basic sociopolitical entities of Preconquest and Colonial times, e.g., the Xiu, Kokom, Itza, Nijaib, Ajaw K'iche', and many other ethnohistorically known social units called chibal, cuchteel or chinamit in Yucatán, Central Petén, and the Highlands (Hill 1996; 
"In the days of my life." Elite activity and interactions in the Maya lowlands

Hill and Monaghan 1987; Jones 1998; Okoshi Harada 2011; Quezada 2014; Restall 1997; Rice and Rice 2007; Roys 1940).

\section{Formation of large intermediate social groups and the end of sacred kingship}

Briefly summarized, archaeological evidence for the emergence of large Terminal Classic social groupings includes new monumentality and the size of residential architecture, transformation of earlier large public structures into huge residential units (e.g., La Danta in El Mirador, Structure II in Calakmul), the contraction of resident populations from small dwellings into adapted elite compounds, social segregation within residential zones, and changing funerary practices (Arnauld in preparation). The seemingly relevant epigraphic evidence on the consolidating identity of those groups, encompasses a proliferation of elite titles in the West and parts of the Puuc in the North, or at least their insertion in glyphic inscriptions (Jackson 2005, 2013; Jackson and Stuart 2001; Lacadena 2008, 2010b; Vega Villalobos 2011), along with the existence in some cases of multiple contemporaneous emblem glyphs in one city, as well as their relocation or pairing (Bíró 2011b; Gronemeyer 2012; Houston and Martin 2016, p. 449-450; Reents-Budet et al. 2012, p. 90-93; Tokovinine and Zender 2012, p. 56-61). It can also be noted that there existed a continuity in the erection of monuments even after the ruler's demise, all of which suggest that non-royal elites had acquired royal symbols. The third category of evidence refers to the increasing intensity of long-distance exchanges throughout the Terminal Classic period, which implies networking and alliance-making over wide territories typical of house societies.

The house society model implies co-residence, ranking and alliance relationships in the determination of sociopolitical dynamics (Arnauld et al. 2013c; Gillespie 2000), by encompassing and articulating archaeologically-based concepts such as household and lineage (rather than excluding them). The model fits state and non-state societies, but applies only to highly hierarchical ones (Carsten and Hugh-Jones 1995, p. 10). It introduces history in our anthropological approaches of Maya cultural change, as advocated by Sabloff (1986, p. 116, cited by Smith 1992, p. 31), a theoretical requirement for our work on generational chronologies involving agents. In the Maya case, this model most efficiently accounts for the demographic growth of intermediate social groups. Co-residence enables us to analyze the monumentality of Late-Terminal Classic residential buildings to which many commoners must have contributed as builders and inhabitants, or co-residents (Arnauld 2012; Arnauld et al. 2013c; Christie 2003; Hendon 2012; Lemonnier 2009; for comparison see Feinman and Nicholas 2016). However, the process was not widespread since in settlements having a higher density of landesque investment (e.g. terracing at Caracol) the latter must have resulted in land inheritance within household lineages and frequent fissioning 
(McAnany 1995, p. 69-99), in turn blocking the development of houses as collective actors (see D. Z. Chase and Chase 2004, p. 141-142). Moreover, with a degree of regional diversity, ranking was internal within social groups-e.g. commoner households affiliated with noble lineages - but also external, between groups forming pyramidal hierarchies up to the apex of what epigraphers call "paramount rulers", "overkings" or "overlords". Martin and Grube have noted that, "while these [Tikal and Calakmul] were twin superpowers [...] they were by no means the only polities to produce 'overkings', and lesser hegemonies developed in every region." (2000, p. 20; see also Grube 2000, Arnauld et al. 2013c, p. 473-474, and Iannone 2010, p. 359-361).

Ranks (or positions in hegemonies) were based not on territories or lands, but on personal ties between lords (Chase et al. 2009; Martin and Grube 2000, p. 20; Okoshi Harada 2000, 2010, 2011, 2012; see also Graham 2006, p. 118, and Jackson 2009). As indicated by the erection of stone monuments, they were periodically waived in highly ritualized performances including inaugurations of buildings, accession to power, and period-ending commemorations. Wide shifts in greater and lesser hegemonies characterize the Terminal Classic period in the Maya Lowlands. Alliance-making was the most prominent strategy for promotion, through exogamous marriage between high-ranked lineages of distinct houses, while endogamous marriage reinforced commoner affiliation (see Arnauld et al. 2013c, p. 484-487 for arguments and references). In this way, a wide web of personal ties, sometimes across large regions, was able to sustain military alliances, loyalties, and probably also tribute obligations (Graham 2012).

Broadly speaking, if the burst of non-royal, monumental-residence constructions over the Lowlands was initiated by AD 700-750, it may be correlated in time with the later weakening of k'uhul ajaw authority. As a case in point, research across many Río Bec residential groups of monumental residences has shown that local societies were firmly structured and prosperous throughout the LateTerminal Classic, although with extremely weak kingship institutions (Arnauld et al. 2014b; Fowler and Arnauld 2013; Arnauld and Nondédéo 2010; Nondédéo et al. 2010; Nalda and Balanzario 2014). Effective political authority should be distinguished from apex positions in local or regional hierarchies. Weak or strong, every sacred ruler was the overlord of somebody and sanctified some hierarchy of titles and names by which subordinate houses were ranked. After the Classic k'uhul ajaw institution (Houston and Stuart 1996, 2001) had disappeared with a number of rulers slaughtered or banished, the need for hierarchy remained among the growing and competing houses. The evidence in monument raising suggests that many new Terminal Classic leaders attempted to retain a degree of the traditional sacred aura and rituals in order to enforce the new ranking systems that favored their own allies (see Martin and Grube 2000, p. 63-64 for an example). In other words, in the current consensus about the collapse of the sacred, or "divine 
"In the days of my life." Elite activity and interactions in the Maya lowlands

kingship" during Terminal Classic times, there may be some confusion between institutions and practices. In the midst of the wide shifts in hegemonies (perhaps the primary, emically-conscious process of the times), some aspects of the sacred institution would indeed have survived into Postclassic times (Grube 2000), whereas political monopolies restricted to the sovereign and his staff would have been transformed into power-sharing practices among noble lords to the detriment of traditional dynasties (Chase et al. 2009, p. 181; Chase and Chase 2014, p. 149). Architecturally, the latter would correspond to the proliferation of large, complex residences combining private and public functions during the early Terminal Classic times (e.g. Demarest et al. 2014, p. 207-208; see also Andrews and Fash 1992; Barrientos 2014; Inomata 2008; Inomata et al. 2002; Fash and Stuart 1991; Fash et al. 2004; Grube 1994b, p. 329, 338). As already suggested, within such an evolution each noble family would have needed strong commoner support as the most determinant asset in the competition for institutional construction.

As mentioned above, the fall of traditional $k$ 'uhul ajawob is not synchronous with the cessation of monument raising everywhere. From AD 830 on, some stone monuments were carved and raised anew, while others were relocated from main public plazas into noble compounds or subordinate centers: see for instance at La Milpa, Tikal, Yaxha, Naranjo, or El Peru-Waka' (Zralka 2008, p. 201; Hermes and Martinez 2005, p. 144-145; Marken 2011; Valdés and Fahsen 2004). Old traditions of public statements were to some extent maintained by the new elite (Tokovinine and Zender 2012, p. 63-64) to their own advantage with new content. One hypothesis would be that, instead of glorifying individual rulers, late Terminal Classic monuments periodically reshuffled or reconfirmed the titles and ranks of local houses on occasions of period-ending rituals (see Feinman 2000, p. 168-170). The practice would be manifested by the change in iconography of many late monuments (see section 4 below; Cases and Nondédéo 2014).

\section{Balkanization, fragmentation, agglomeration}

Diverse urban components, including capitals and their subordinate settlements (e.g. Scherer and Golden 2014) increasingly interacted, resulting in Terminal Classic changes conceptualized as a "balkanization", "decentralization", "fragmentation", and "elite proliferation" (Aimers 2007, p. 344, 346; Demarest et al. 2014, p. 207; Fash and Stuart 1991, p. 175-176; Houston and Stuart 2001, p. 73-76; see also Iannone et al. 2014, p. 60). Referring to an Eastern site (Minanha), Aimers and Iannone (2014) use the concept of "societal compression" to stress that at both ends of Terminal Classic Maya societies, royal elites and unaffiliated commoners may have been impacted by cultural and natural dynamics, whereas intermediate groupings were reinforcing positions and prospering, especially those controlling any permanent water source (see also Iannone et al. 2014, p. 64). Both "societal 
compression" (on the social scale) and "fragmentation" (political scale), adequately capture the entire transformation of traditional Classic societies. However, attention should also be paid to what those processes implied in concrete terms, i.e. the gathering of people affiliating, gradually or rapidly, to powerful families living in prestigious residences. This aspect of compression and fragmentation is seen in the agglomeration or coalescence of large co-residence groups, and may become archaeologically visible at least in many settlements through shifting occupational rates in site sequences, and withdrawals from small houses by commoners moving to cluster within and around elite compounds, resulting in the contraction of residential zones (see, among others, Arnauld et al. 2013b, 2014a; LeCount and Yaeger 2010, p. 75-76; Marken 2011; Nondédéo et al. 2010, p. 50, 2013a, p. 379, 381-382; Sion 2014; Taladoire et al. 2013, p. 361-364; Valdés 2005, p. 59-60; Zralka 2008, p. 129, 131; Zralka and Hermes 2012, p. 181). Agglomeration also corresponds to what is frequently described as internal modification of large compounds, with enclosures, division of dwelling spaces, additions of benches, and narrowing of entrances (Laporte and Mejia 2002; Hermes and Martinez 2005; Sion 2014, in press; Valdés 2005, p. 58; Zralka 2008; Zralka and Hermes 2012). Such changes imply that more people were integrated than segregated from the rest of the population.

\section{Physical houses}

The diversification of functions in residential compounds has only recently been explored and much still has to be elucidated in Late-Terminal Classic residential architecture (e.g. Christie 2003). In contrast with its Early-Late Classic counterpart, the complexity and monumentality cannot be overemphasized, especially in the East-Central and Northern Lowlands (Figure 1) where the Río Bec, Chenes and Puuc styles characterize extraordinary residential architectures. The latter became so prevalent that they almost replaced public religious architecture (Michelet et al. 2013; see Braswell et al. 2004, p. 179; Hansen et al. 2008, p. 45-46 for cases of temples transformed into residential spaces at El Mirador, Calakmul and Tikal; also, Morales Aguilar 2012). Physical houses were the core of the newly formed groupings. As places of memory, of ancestral cult and "mutual knowledge" (Hendon 2000, p. 49) about the exact location of ancient buried deposits, they were sacred sites that transmitted names, titles, emblems, and stored properties (Beck 2007; Gillespie 2010; Hendon 2010; Iannone 2010; McAnany 1995).

To summarize, there is already a large corpus of evidence showing that by the eighth to ninth centuries, numerous intermediate social groups had emerged that questioned the authority and ranking imposed by the long-lasting hegemonies of sacred dynasties. The power of those groups lay in the political, economic (based on long-distance trade and, possibly, on markets), and mostly 
"In the days of my life." Elite activity and interactions in the Maya lowlands

demographic bases, with military capacities and access to tribute at stake. Agents in those groups were able to act corporately, to make alliances with outsiders and foreign groups, and to make at least part of their group move to new places. However, an unknown proportion of Maya populations probably never integrated into those houses, and was thus left with the option of staying unprotected in declining cities or dispersing into forested hinterlands. Agents well incorporated into large groups had more decision-making options in the volatile circumstances of Terminal Classic times, and the effects of their actions have fortunately left more visible traces than their isolated counterparts. In this work we explore the generational sequences of events and rapid processes brought forward by those actions, since individual actions taken by commoner families are more difficult to trace through settlement variation and dynamics.

\section{Variables, focus, and time resolution}

While not exhaustive, precisely dated information for the AD 750-1050 interval was gathered from a wide bibliographical review led by Demarest et al. (2004a) and Aimers (2007) who produced outstanding syntheses, with the contribution of many recent papers on sites in the Northern, North-Eastern, Eastern and Western Lowlands (Figure 1). Other datasets come from the results of the archaeological research projects in which we were (and still are) involved at a number of sites - in the North: Xculoc, Xcochkax, and Xcalumkin; in the North-East: Balamku and Río Bec; in the East: Naachtun; in the West: La Joyanca, Zapote Bobal, and Cancuen-reinforcing our sensitivity to the ecological and sociopolitical diversity of the Maya lowlands, along with the wide range of processes the regions went through, even though our narrative must follow the primarily generational time guide.

\section{Variables}

We have limited the research collected to the following four variables (Figure 2, next page):

- dedication of sculptured stone monuments, as an expression of whatever political institutions were functioning in the city in which they were erected and revered;

- warfare, conflicts, and violence;

- monumental construction in epicenters and residential zones of cities;

- presence/absence of, and rapid shifts in, the resident population of cities.

Except in some cases, monument erection, warfare, monumental construction, and residential occupation did not end simultaneously in any one city, and acknowledging their diachronic endpoints is a priority (see a brief discussion by Andrews et al. 2003, p. 152). The four variables were selected due to the like- 


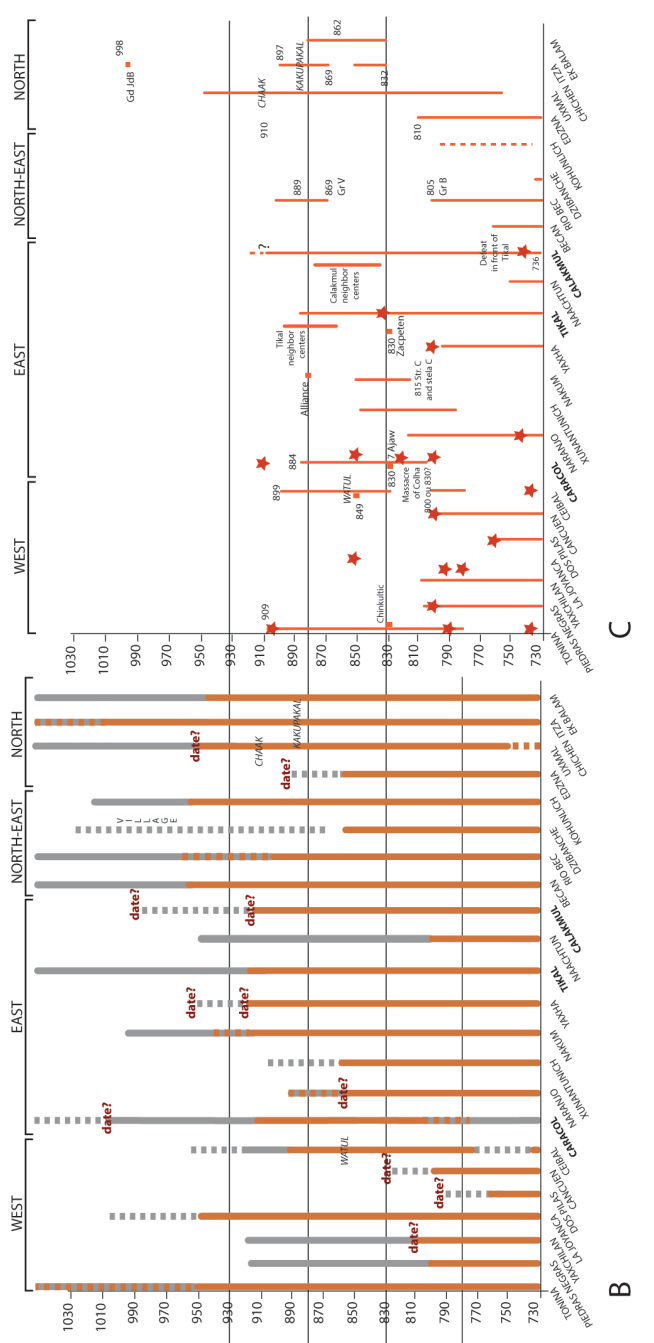

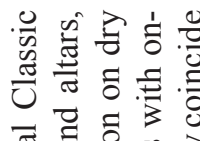

켤.

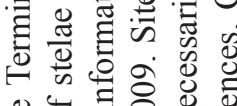

\& $4 . \Xi$ 웡

棺. 들

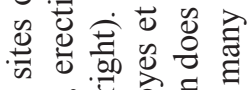

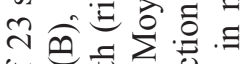

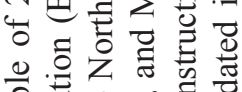

총

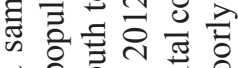

๙

$\Xi$ 苛芯芯䒕

记

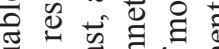

矛焉

‡ี

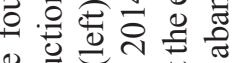

छ

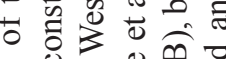

ชั

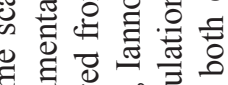

ఏコ一心

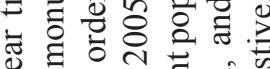

$\lambda \bumpeq \lambda$ 若

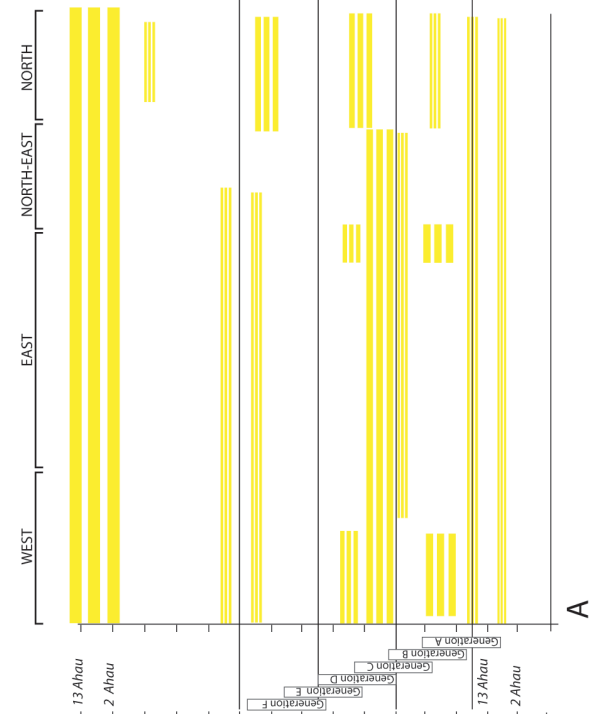

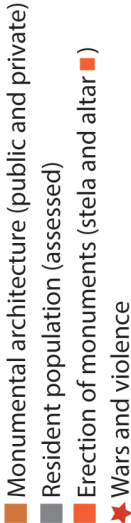
ป ๙

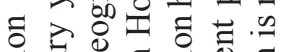

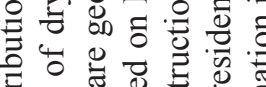

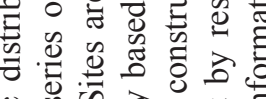
.

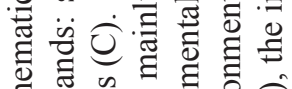

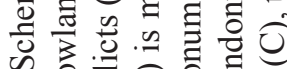
थ N $\pi 8$ क

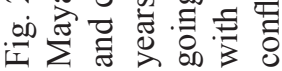

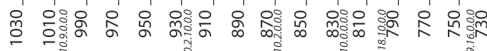


"In the days of my life." Elite activity and interactions in the Maya lowlands

lihood that, emically, they generated information that circulated among social groups, and was transmitted through at least two sequent generations as the basis for chains of decision/action. Etically, the same variables document diplomatic action and population mobility (see below). We also take into account multidecadal drought episodes as established by recent paleoenvironmental research (mainly Hodell et al. 2005, Hoggarth et al. 2015, Iannone et al. 2014, Kennett et al. 2012, and Moyes et al. 2009). However, the lowland geographical and agrarian diversity is such than rainfall variations did not affect all subsistence systems and regions in the same way.

\section{Elite diplomatic action and population mobility ${ }^{2}$}

We are fortunate in being able to draw upon a massive amount of information, but a general synthesis is beyond the scope of this paper. We will focus on two specific types of decision/action with far-reaching consequences: elite "diplomatic action", and commoner "population mobility". The former is a direct function of hegemonies, house ranking and alliance-making (see section one); the latter an indirect function of elite competition, and possibly also a direct result of climatic conditions. Diplomatic action includes all ritualized performances in which ranked persons gathered in search of matrimonial and military alliances, as well as the redefinition of regional rankings under traditional or new overlords. Certain forms of warfare should also be considered (Inomata and Triadan 2009; Tokovinine and Zender 2012). Diplomatic action can thus be documented mainly through the first two variables, monument erection and warfare, and through monumental construction also. Population mobility, with residence shifting either from city to city, or from city to hinterlands, was common during the Classic period in relation to milpa agriculture, pilgrimages, markets, itinerant production, and exchanges (e.g. Freiwald 2011). However, the Terminal Classic period would have seen an acceleration of a new (previously rare?) kind of mobility, namely the relocation in space of sociopolitical groups, perhaps "mass migration" in some cases, or more limited moves in others (Demarest et al. 2004b; Demarest 2006; Rice and Rice 1990, 2004). Migration challenges the co-residence principle-basic in house societies - since groups had to abandon their traditional residence and relocate to different contexts. Indeed, later Yucatán Postclassic social groups lived only

2. Since the present study does not focus on social houses, we avoid developing a model of diplomatic action and mobility derived from the current knowledge of Classic Maya houses. Such a model should, however, be worked out in order to give more substance to the general characterization of the Terminal Classic moment as one of sociopolitical fragmentation, intensified exchanges, and population movements. It would also help to clarify the Epiclassic 'Mesoamericanization' process (e.g. López Luján and López Austin 1999; Ringle et al. 1998). 
partly in co-residence (e.g. Okoshi Harada 2012). Population movements can be approached through the last two variables: intensity in monumental construction (Zaro and Houk 2012), and continuity/rupture in resident population: see hinterland studies such as on the Petexbatun area (Eberl 2014; O'Mansky and Dunning 2004; Tourtellot 1970), El Peru-Waka' (Marken 2011), Xunantunich (Yaeger 2013), La Joyanca (Arnauld 2013; Arnauld et al. 2013b).

Diplomatic actions and population movements must be envisioned within the framework of the Terminal Classic geopolitical transformations reflected in a wide shift in settlement locations, mostly from the interior lowlands to the coasts (Dunning et al. 2012; Turner and Sabloff 2012). Both collective action types imply complex, off-routine chains of decision-action led by many great and petty rulers and leaders alike. Ideally we need to investigate what information was available to those agents at specific moments and places, what the circumstances were for decision-making, and what could have been transmitted through generations. This paper is intended to provide the main guidelines for such exploratory work, setting the theoretical framework and dataset synthesis, but is dependent on the state of research in archaeology, which still lacks the degree of quantitative evaluation necessary for graphical expression.

\section{Chronological resolution}

The fifty-year time span was selected for the following reasons. In the demographic context of the ancient Maya it corresponds to one lifetime, and also to two sequent generations (parents and children: e.g. Marquéz and Hernández 2013). It can be equated to a little more than two Maya katunob (20-year calendrical cycle), and almost exactly to the 52-year cycle determined by the return of the same day name and coefficient-year bearer-in the conjunction with the haab (solar year, 360 days +5 days) and sacred tzolkin (260 days). The katun and its five-year quarters were the most celebrated calendar periods in the Maya cities, as witnessed by numerous dated inscriptions on carved stelae and altars (Stuart 2011). These Long Count calendar dates provide a canvas precisely anchoring in time any associated materials, ceramics, architecture or deposits. However, not all Maya cities erected stone monuments, and in many cases the historical or circumstantial meaning of the inscribed dates is lost, particularly the dates on the last monuments (Ebert et al. 2014; Aimers and Iannone 2014; on the significance of Maya Classic monuments, see Christie 1995, 2005; Gillespie 2010, p. 406-407; Newsome 1996, 2001; Stuart 1996).

Ceramic chronologies are still far from such chronological resolution. Archaeologists have long tended to consider Terminal Classic site components as short and catastrophic phases that do not need to be subdivided (Rice and Forsyth 2004, p. 53-59). However, resolution is gradually improving 
"In the days of my life." Elite activity and interactions in the Maya lowlands

and sequences with two to three Terminal Classic subphases have now been established (since Ceibal, Sabloff 1975; Forné 2006; Forné et al. 2010, 2011; Martinez and Forné 2014). Radiocarbon dating calibrated along Bayesian models also refines ceramic intervals (e.g. Hoggarth et al. 2014, 2015; Volta and Braswell 2014). There are few reported Terminal Classic radiocarbon dates in published sources, a dearth due to limited sampling in surface strata (e.g. Ebert et al. 2016; LeCount et al. 2002). In the present study all absolute chronological information is entirely based on dating provided by the authors of compiled sources. Although quite useful in this context, dated site construction sequences are not plentiful; nor are surveys in hinterland occupations that might help date population mobility and possible late (post AD 920) demographic collapse. Clearly the resolution/precision problem derives from the fact that the observed variables are dated on the basis of widely diverging methods (Hoggarth et al. 2014). There is not much we can do about that situation, except multiply cross-dating, site sequences, and surveys.

At this point, it may be necessary to stress that unfolding events and processes along a generational time span does not result in the detection of cause (see Bailey 2007, and Smith 1992). Rather, it attempts to elucidate the conditions of decision-action experienced by generations in Maya Terminal Classic societies. Two aspects are involved here, the acceleration of change in a lifetime (see endnote 1), and the replacement of one generation by another (Carsten and Prechtel 1991; Gillespie 2010, p. 404-405; see also Houston and Inomata 2009, p. 55-60). On the basis of the information compiled, we surmise that at least some of the events and processes developed rapidly enough to be perceived by individuals in their lifetime, and that they were in a position to react to these themselves and through their offspring. We selected three fifty-year intervals that together cover the Terminal Classic period from AD 780 to 920. Although AD 780 is a midpoint between the lower limits of Western and Eastern Terminal Classic site phases, we eventually opted for AD 760 instead of 780 to accommodate the early processes in the Western Lowlands. AD 830 closes the ninth cycle, Baktun (pik) 9, and opens Baktun 10, in the Maya four hundred-year calendar period. It is also the traditional date assigned to the incipient general distribution of fine-paste ceramics across the Lowlands. By AD 870 few cities still erected stone stelae and altars. AD 920 is a midpoint in the gradual emergence of "International-style" Chichen Itza with Sotuta-Sotuta ceramics (Volta and Braswell 2014). It is also the time of worsening rainfall conditions (e.g. Hoggarth et al. 2015).

\section{AD 760/780-810/830: Warring kingdoms and houses}

Before AD 810 most of the Western Lowland cities (Figure 1) had lost their royal dynasties and part of their resident populations. Concomitantly they 
stopped building monumental architecture and raising carved stelae and altars. One generation before, in AD 761, the defeated Dos Pilas dynasty fled to Aguateca, after which a series of conflicts terminated most cities along the Río Usumacinta and the Petexbatún region. Unstable conditions certainly prevailed even before 761 throughout the entire western side of the lowlands. Perhaps as the outcome of the defeat of Calakmul by Tikal (AD 736), La Corona, La Florida, El Peru-Waka', Zapote Bobal, and other northwestern cities had ceased stelae erection, but they were not necessarily deserted. Indeed there was much diplomatic activity (and warfare) between these cities, Yaxchilan and Motul de San José by AD 796-800 (Tokovinine and Zender 2012, p. 56), and Waka' soon even appear to be crowded, whereas the hinterland was mostly abandoned (Marken 2011) $)^{3}$. In the extreme south, Copan also lost its royal dynasty by 810-820 (Fash et al. 2004; Manahan and Canuto 2009). Over two generations (AD 761-810), the geopolitics of many parts of the lowlands had radically changed (see Houston and Inomata 2009).

\section{The Western Lowlands from 760 to 810}

While the temporal sequence of post-760 events is well known thanks to the numerous Petexbatún, Cancuen, Aguateca and Ceibal project results (Demarest 2013b, 2014; Demarest et al. 2004a, 2014; Inomata and Triadan 2013; Triadan 2012), the data from the hinterland of the Petexbatun project show that people started to move away before 760 (Eberl 2014; Inomata 2004; O'Mansky 2014), suggesting that the roots of the crisis are to be found long before the limits of what is considered the Terminal Classic. It is unclear whether kingdoms, or their internal factions, or both, initiated and stimulated the endemic warfare condition. In any case, the conflicts did not aim to conquer territories given that victorious parties did not impose new dynasties (Inomata and Triadan 2009). If noble houses rebelled against rulers, then they apparently fell into endless rivalries. Epigraphist Peter Biro stresses that Western royal dynasties may have intruded from the East_-Dos Pilas was at least ruled by a splinter faction from the Tikal dynasty (Biro 2013; Houston 1993). Their legitimacy might have been more easily challenged in times of crisis.

By AD 760-780 rapid changes in residential zones and bursts of monumental construction activity signal population shifts into Aguateca (Ponciano et al. 2013), as well as into Cancuen, a fluvial port on the upper Río Pasión (Demarest 2013a, 2013b; Demarest et al. 2014). Both cities profited from the Dos Pilas defeat (Demarest et al. 2009), although Cancuen had been allied by

3. In contrast, it is well known that Tonina, in the extreme west, and Itzimte, close to Motul, in the East, each erected one last stela very late in AD 909 and 910 (Ebert et al. 2014; Eppich et al. 2005; Golden and Scherer 2013, p. 416). 
"In the days of my life." Elite activity and interactions in the Maya lowlands

marriage to Dos Pilas (Houston 1993). The large Cancuen palace was renovated and expanded (Barrientos 2014), while ruler Tah Chan Ahk defeated neighboring Machaquila and Sak Witz (Fahsen and Demarest 2001; Fahsen et al. 2003), and launched an original strategy of long-distance trading reaching as far as Tabasco and the Chontalpa region (Veracruz, Mexico: Andrieu et al. 2014; Demarest and Martinez 2010; Demarest et al. 2012, 2014; Forné et al. 2013, 2014). This clearly avoided the Petexbatún route, which was rife with conflicting factions.

What followed is well known and has been narrated elsewhere (Demarest 2004, 2006; Demarest et al. 2009, 2014; Houston and Inomata 2009, p. 295-304; Webster 2002, p. 274-283 among others). Briefly, in AD 800 Cancuen was attacked and defeated by a victorious party which, for the first time, did not claim the deed in one of the many war narrations then frequently carved on stone (Demarest and Martinez 2010). The Cancuen royal family was slaughtered, the ruler hastily buried in his palace, and other human remains were left unburied in the main port (Barrientos et al. 2006; Barrientos 2014; Suasnavar et al. 2007). Coincidentally in AD 801, the new Machaquila ruler, Ochkin Kalomte, raised a stela (suggesting that he may have originated the attack against Cancuen), engaged in monumental construction work that remodeled the entire city in less than 50 years, and imported ceramics from the Eastern coast (Ciudad Ruiz et al. 2013). The rural hamlets and villages of Petexbatún were then either depopulated or fortified, indicating that warfare was already endemic. In 810, Aguateca stopped building Structure L8-8 (a pyramidal temple) and fortified the epicenter, which was, however, soon taken and burnt down by an unknown party (Inomata 2008; Inomata and Triadan 2010; Ponciano et al. 2013). Since Terminal Classic ceramic diagnostics were not found in hinterland settlements, we can suppose that they were deserted (Inomata 2004). Further down the Río Usumacinta, by AD 810 dynasties fell at Yaxchilan, Piedras Negras and their intermediate subordinates, but were not depopulated. According to Golden and Scherer (2013, p. 416) "post-dynastic residents are best understood as local populations that endured for generations after the death of the courts". Even though those stoic populations did not massively migrate, dynastic collapses certainly disrupted trading capacities, alliances, and hierarchies. At the same time, Ceibal entered a period of crisis (Sabloff 1973), and stopped construction until 830 (Inomata and Triadan 2013). What happened in the Petexbatun is probably the most radical and violent succession of events within two generations (AD 760-810). An important part of the Western Lowlands was abandoned, sacked, and would never be reoccupied again.

\section{New Eastern hierarchies from 760 to 810}

By then, it seems that no other Lowlands region was experiencing the dramatic processes of the West, with the possible exception of some areas in 
Northern Belize (see below). In AD 795, among northeastern sites, some large Río Bec groups still erected stelae at the onset of the apogee in the local style (Nondédéo et al. 2010), whereas there was apparently no political activity in Dzibanche after the Calakmul defeat (AD 736; Nalda and Balanzario 2014). At Becan the resident population underwent spatial contraction and a burst of Río Bec-style monumental construction (Nondédéo et al. 2010), although this is interpreted by Ball (2014) as a temporary abandonment of the site due to the limited Chintok ceramic evidence and the lack of royal activities in monument raising and burial practices.

Among the eastern cities, Calakmul and neighboring sites were still substantially populated and active, raising monuments (except for Naachtun after 761, see Nondédéo et al. 2013b, Nondédéo and Michelet in press), trading, and adopting some Río Bec-style features, whereas Tikal launched the construction of Temple III (associated with Stela 24 dated to 810). Tikal was victorious against nearby Yaxha in AD 799. After the Calakmul defeat (AD 736), although with no apparent loss of prosperity nor any monumental construction, Caracol ceased to erect monuments during the eighth century, but resumed the practice by AD 798 (Chase and Chase 2003; Chase et al. 2009), "with a new focus on dynasty and situating the new rulership within a broader Maya worldview" (Chase and Chase 2014, p. 150). Interestingly, "[...] all through the ninth century, rulers appear to have shifted on a regular basis, possibly reflecting a different organizational structure consistent with a non-dynastic batabil form of government known from the Postclassic northern Lowlands" (ibid.; see also Chase and Chase 2015). In the surrounding cities, glyphic texts narrate wars raging in AD 779-780 between Ixkun, Sacul, and Ukanal (Laporte 2004, p. 224; Martin and Grube 2000, p. 97). The royal palace at Minanha was filled in by 810 (Iannone 2010, p. 364-365), as was the Ottawa Group at Lamanai, where elites shifted from stone to largely wooden architecture (probably AD 750-800; Graham 2004; see other cases of infilling in Zaro and Houk 2012, p. 156). At the same time, from AD 790 onwards, other stelae and altar inscriptions record alliance-making visits to Ixkun and Sacul (Laporte 2004, p. 224), with or without Caracol maneuvering regionally. This might be one of the earliest sign of ninth-century diplomatic activity detected in the lowlands, along with the dedication in AD 800 (9.18.10.0.0) of Altar 3 at the Altar de los Reyes site (north of Naachtun) featuring a list of thirteen entities, dynasties, and/or prominent houses, among which Tikal, Calakmul, and Motul (see Grube 2008, and Tokovinine and Zender 2012, p. 56, 61-65) in a plausible redefinition of then current regional hegemonies. Another attempt in the southeast would be represented by Ixtutz Stela 4, dedicated in AD 780 (Zender 2002).

It should be noted that, by then, the subordinate settlements surrounding the three great capitals were increasingly active in monument raising and monumental construction. Though dramatic in the Western Lowlands, the 760-810 
"In the days of my life." Elite activity and interactions in the Maya lowlands

period shows all the signs of elite activity and interaction reflecting diplomatic and economic strategies required to face political changes. Evidence of longdistance exchanges in particular indicates that the elites were attempting to reorganize new networks and alliances to suit new priorities.

\section{Looking for new trading routes from AD 760 to 870}

To what extent did royal dynasties ever control long-distance exchanges and markets? The highland/lowland exchange trading routes were considerably affected by the Petexbatun crisis (at least with the end of the Cancuen harbor on AD 800). Curiously, however, at sites that retained a resident population after $\mathrm{AD} 810$, we observe a tendency for a broader distribution of the obsidian imported from the Guatemalan Highlands in larger quantities. That is clear at Piedras Negras where obsidian quantities increased 10-fold at that time (Hruby 2006), even though there is no longer any hint of royal power at the site after AD 810. A similar trend has been noted in the Tikal-Yaxha transect, where obsidian is more frequent and evenly distributed outside the civic ceremonial centers at that time (Rice 1987). The same has been observed at Tikal (MoholyNagy 2003), at Río Bec (Andrieu 2009), and at Naachtun (Andrieu and Sion in press). The obsidian from the Mexican Highlands becomes more frequent and widely distributed from the onset of the Terminal Classic (Andrieu and Sion in press; Braswell and Glascock 2003). These changes probably indicate a major shift in the distribution system in obsidian exchanges that remains to be understood.

Also of great relevance are the shifts in material culture, which include the emergence of non-polychrome, fine-paste ceramic vessels with new forms. Chablekal Fine Gray and Campamento Fine Orange dating to AD 760-780 the earliest, Tres Naciones Fine Gray, Altar and Pabellon Fine Orange dating to AD 830 (or earlier?) were introduced from diverse western regions (Bishop et al. 2005, 2006; Foias and Bishop 1997, 2005, 2007; Forné et al. 2010, 2011, 2013; López Varela 2005), as well as non fine-paste Ahk'utu' vases in Belize (Helmke and Reents-Budet 2008; Ting et al. 2014). Whether their degree of distribution was socially wider than that of Classic polychromes is a matter of debate (e.g. Chase and Chase 2005). But clearly, even if production tended to be regionalized (with frequent imitations), those ceramics rapidly became standardized finewares shared by most cities across the lowlands. Such change points to a restructuring and broadening of social negotiations (A. F. Chase and Chase 2004, p. 360, 364; Ringle et al. 1998; Ting et al. 2014), as well as alliance-making activities among intermediate social groups (Helmke and Reents-Budet 2008, p. 47).

Other, less-studied trade networks expanded, such as those for granite manos and metates from the Maya Mountains, which seem to represent about $60 \%$ of 
the grinding stones in Terminal Classic Naachtun, while also being present in Tikal (Moholy-Nagy 2003), and in Nakum (Zralka pers. comm. 2013). This was accompanied by a broader distribution of other Belizean wares such as Red Belize ware (Harrison 2000; Chase and Chase 2012). With new routes opening (Andrieu and Sion in press; Golitko et al. 2012; Sion 2016) exchanges over hundreds of kilometers imply that elites from different sites entered into firm alliances and agreements on logistics and production-exchange conditions, trying to avoid old networks and to renegotiate new routes. Emerging networks, their modalities and spatial extent are still insufficiently researched and poorly understood (including tribute obligations: Graham 2006, 2012). Yet, economic networks might provide proxies to the social reorganization of the Southern Lowlands, as well as to their growing interaction with the Northern Lowlands.

North-South interactions before AD 830: ideas, goods, styles, and movement of people

Considering the late development of architectural styles from the North-Eastern to the Northern Lowlands (Río Bec, Chenes, Puuc), it is amazing how rapidly some of those elements spread to the Western (Inomata et al. 2004; Ponciano et al. 2013), and Eastern Lowlands (Chase 1985; Chase and Chase 1982; Harrison-Buck and McAnany 2013; Nondédéo and Michelet in press). The maritime route (on the eastern coast) certainly facilitated movement, resulting in a volatile situation among coastal and hinterland cities, with the episode of violence at Colha and the takeover of Nohmul as possible Northern deeds (Aimers 2007, p. 342-346).

Between AD 751 and 820 Dzibilchaltun, Puuc Oxkintok and Uxmal erected series of stelae, while Chichen Itza was still a modest center. Puuc-style monumental residences signal the emergence of large intermediate social groups. Ek Balam and Uxmal appeared internally divided by walls, either for defense or the segregation of distinct neighborhoods, or alternatively against outsiders attending market plazas (Ringle and Bey 2004, p. 506, 507, 510; Carmean et al. 2004, p. 427). Then, from AD 820 to 850 there was a hiatus in stela dedication in Oxkintok, whereas by AD 810-830 Uxmal had adopted a new stela iconography incorporating the multiple-figure "panel" style (Carmean et al. 2004, p. 427, 429-430). Both shifts would suggest that houses gained in autonomy against dynasties, or that many petty rulers were developing alliances (see Michelet et al. 2000, p. 523).

In the east, the powerful city of Naranjo ceased to erect stelae in AD 820 and fell out of trade networks, leaving a void that resulted in competition among Eastern kingdoms and houses. Xunantunich erected its first stelae, while Yaxha recovered from its defeat by Tikal (AD 799), resumed monumental construction, and then stela dedication. At the same time, Nakum launched enormous 
"In the days of my life." Elite activity and interactions in the Maya lowlands

palatial construction programs and benefited from a demographic surge (Zralka and Hermes 2012, p. 181). Before AD 830 Nakum seems to offer an array of imported styles, including even from Xochicalco in the Mexican Highlands, and a multiplicity of reception and dwelling rooms (Zralka 2008, chapter 3) that suggest a remarkable capacity in long-distance interaction and alliance making.

\section{The last katun in Baktun 9}

In evaluating the evidence for the AD 810-830 time span, one is struck by the acceleration of interregional interactions. This raises the issue of chronological resolution, as our impressionistic evaluation may not capture the extent of the shift in relation to the preceding and succeeding time intervals. However, in the same last katun, stone monuments and their content deserve special attention, since by then the number of stela-altar erections had sharply decreased in comparison with the eighth century (Ebert et al. 2014; Kennett et al. 2012, fig. 2). Moreover, as N. Grube (1994a, 2013) observed long ago, inscriptions ceased to narrate war events, which implies a public silencing of warfare rather than an effective general peace. Both observations may be another early sign of later changes in epigraphic and iconographic contents. Maya agents born in $\mathrm{AD} 780$, informed about events in the Western kingdoms and engaged in prosperous activities, may have also assessed the situation under the premise of Cycle 9 ending in 10.0.0.0.0, AD 830, and the incoming Cycle 10. How to connect the elements of this $810-830$ katun sequence raises intriguing questions (Houston and Inomata 2009, p. 301-304).

\section{AD 810/830-850/870: making alliances}

Although a few site sequences place the lower limit at AD 850, this time span falls in the full Terminal Classic period. Recent speleothem research on climatic variation reports "[...] a series of multi - decadal droughts from AD 820915, AD 930, and an extended severe drought from AD 1020-1100 (Kennett et al. 2012)." (Hoggarth et al. 2015, p. 6). The investigated cave is located in southern Belize (South-Eastern Lowlands) at Yok Balum, a distant location, which raises doubts about the impact of such events across the entire lowlands. However, droughts recorded historically from 1500 to 1800 in northern Yucatán show a good temporal correlation (within dating errors) with some of the dry episodes of the Yok Balum record, and in addition, four distinct speleothem and lake records dispersed from the Northern to the South-Eastern Lowlands also show those two multi-decadal dry episodes temporally correlated with Yok Balum, i.e. AD 820-920/930 and 1020-1100 (Hoggarth et al. 2015). Both intervals offer the most robust evidence so far, whereas previous droughts are shorter, thus have higher dating uncertainties, as also does "a [intermediate] period of 
increased precipitation from AD 858 to 890" (Hoggarth et al. 2015, p. 3, citing Medina-Elizade et al. 2010, and Kennett et al. 2012; Webster et al. 2007). It is therefore relatively safe to posit that the political changes that occurred before 810 were not necessarily drought-induced, and that the first katun of the Tenth Cycle, AD 830-850, was probably perceived by many Maya agents as adverse in terms of rains. Its real impact on the diverse subsistence systems of the lowland regions is a distinct issue (see Iannone 2014).

In the Eastern Lowlands many ritual deposits and domestic middens reflect intensified trading activities both in diversity and quantities of goods, along with ceramic changes pointing to new ways of food preparation and sharing (Aimers 2007, p. 337, 2004; Mock 2005, p. 123, 1997, p. 165-183; Masson and Mock 2004; Sion in press). Current generations (people born by AD 800-820) were certainly also aware of population movements taking place around Tikal, Naranjo, Ukanal, and Calzada Mopan, archaeologically reflected by rapid shifts in occupation rates (Hermes and Martinez 2005; Laporte 2004, p. 225-228; Laporte and Mejía 2002; Zralka 2008, p. 204, 209-212). However, we are unable to differentiate regional inter-settlement mobility linked to diplomatic activity and warfare (see Yaeger 2013; Freiwald 2011, 2013; LeCount and Yaeger 2010), from dispersal into the hinterlands possibly caused by subsistence risks due to poor rains. In any case, Tikal, Caracol, and Calakmul maintained substantial resident populations (Braswell et al. 2004; A. F. Chase and Chase 2004; Valdés and Fahsen 2004). Considering the climatic, calendrical, and political circumstances of the AD 810/830-850/870 interval, more research is needed specifically on urban demographic stability and instability. Collective diplomatic action is somewhat better documented.

\section{Signs of diplomatic activity}

From AD 830 to 870 the number of sites still dedicating stelae and altars was relatively stable, although raw numbers of monuments appear to drop (Kennett et al. 2012, fig. 2). This is due in good part to a clear shift toward secondary centers. As mentioned earlier, secondary centers around Caracol show erection activity starting AD 810 (including Xunantunich, Nakum, Yaxha, Ukanal: A. F. Chase and Chase 2004; Chase 1985). Around Calakmul the same activity was more recent, from AD 830 (Oxpemul, El Palmar, and La Muñeca), whereas around Tikal (Ixlu, Jimbal, Zacpeten, Xultun, and Uaxactun) the Tikal glyph emblem was not used until 859 (Martin and Grube 2000; Rice and Rice 2004; Rice 2004; Valdés and Fahsen 2004). Confirming this decentralizing trend, $65 \%$ of Tenth Cycle monuments (post-830) were erected in second-to-third rank centers, and $40 \%$ were in centers that had only one monument in their whole sequence (Houston 1993; Marcus 1976, p. 192-193). Interestingly, in many cases these late monuments present poor quality inscriptions, indicating 
"In the days of my life." Elite activity and interactions in the Maya lowlands

that they were not made by the same royal artists as in the previous generation. We suggest that such activity had to do with the emergence of new regional and sub-regional hierarchies of intermediate social groups under the declining aegis of the great capitals.

In the East, there is good evidence after AD 830 for numerous cases of abrupt destruction of thrones, benches, and palaces (Aimers 2007, p. 344; Arnauld et al. 2013a, p. 160; Graham 2001; Iannone 2005; Laporte and Mejía 2003), a phenomenon that had already began earlier elsewhere (e.g., Dos Pilas in 761, Piedras Negras in 810, Copan where Altar L was left unfinished in 822: Martin and Grube 2008). Whereas war narrations or mentions are rare, the iconography of captives is still common on altars and stelae, reflecting the persistence of traditional capture warfare. But simultaneously, iconography and inscriptions expressed a concern for local and regional alliances, a trend that has long been noticed by D. Stuart (1993, p. 337) and A. Chase (1985) who pointed out frequent conversation scenes involving several persons, similar to the Northern “panel” style (Grube 1994a; Rice and Rice 2004, p. 133-134; Zralka 2008, p. 213). "Common Terminal Classic iconographic motifs such as the presence of two or more individuals facing each other in alliance or consultation occur on pottery and monuments..." (Chase and Chase 2005, p. 88). The same scenes appear on ceramic Pabellon molded-carved vases, or their Petén and Belize imitations (Helmke and Reents-Budet 2008; Rice and Rice 2007, p. 155-156), and on a series of carved benches in a Río Bec residence (Group B, Arnauld and Lacadena 2004; see McVicker and Palka 2001, p. 195 for the same seated figures on jade plaques as "alliance gifts"). This indicates that the agents were not only rulers but also household heads engaged in diplomatic activity ${ }^{4}$. The evidence is limited to the Eastern and North-Eastern Lowlands, but in the meantime Western leaders were not inactive.

\section{Attempts at a New Order at Ceibal}

At Ceibal, one of the few Western cities to remain populated, the event that occurred in AD 849 seems central to the 830-870 time span, although alternatively it may have been a rather anecdotal and conservative attempt to restore old times (see below). After a long crisis that initiated in AD 735, followed by political disruption (Houston 1993; Houston and Mathews 1985), Ceibal was revitalized in 829, just at the onset of Baktun 10 (Schele and Mattews 1998), by "the arrival" of a new leader named Aj Bolon Ha'bte Wat'ul K'atel, who claimed to have come from Ukanal. As an Eastern center linked to Caracol,

4. Although with named kings, the same diplomatic and ritual scenes are represented on polychrome vessels produced at Motul de San José (the "Ik" site) and studied by ReentsBudet et al. (2012), in a tradition that ended by AD 810. 
Ukanal was one of those emerging cities already involved in diplomatic activities (Martin and Grube 2008, p. 227; Stuart and Houston 1994, p. 20, 21), and receptive to innovations and people from the North. The evidence indicates that this intrusive leader respected Ceibal's past, its local titles and emblem glyphs (see Triadan 2012, p. 168).

The event is well known and has been commented upon since it was discovered in the 1970s (Coggins 1990; Graham 1990; Houston and Inomata 2009, p. 306309; Marcus 1976; Martin and Grube 2000, p. 53; Rice 2004, p. 206-214; Schele and Mathews 1998, p. 185-187; Smith 1982; Tourtellot and Gonzalez 2004; Triadan 2012; Vega Villalobos 2011; Inomata and Triadan 2013, p. 63). It is sufficient to say that a ceremony was held celebrating the katun ending on 10.1.0.0.0 (the first katun in Baktun 10) at a specially built plaza centered on Structure A-3, a small radial platform supporting a temple with five beautifullycarved stelae, one inside and four at the base of the four platform stairways. The A-3 upper stucco frieze includes the date 7 Ajaw 18 Sip, probably 10.0.0.0.0 (Rice 2004, p. 208). All five stelae display the Classic traditional image of the ruler (Wat'ul) standing by himself. The associated Stela 10 inscription relates that this ruler carried out the rites assisted by the rulers of Tikal (Mutul), Motul de San José (named Kan-Ek, or Chan Ek Noj Pet), and Calakmul (Kaanul). Stelae 9 and 8 also mention Lakamtuun, and the enigmatic city called Puh (Inomata and Triadan 2013, p. 63) .

The extraordinary royal iconography of the five stelae (until recently interpreted as non-Maya and intrusive, see Stuart 1993, and Tourtellot and Gonzalez 2004), the remarkable mastery of design and carving, with the intricate mix of old tradition and new standards, all suggest that the specific ritual was a salient moment in political and diplomatic activity. Structure A-3 as a radial platform, prefigures the Castillo at Chichen Itza and later similar temple-pyramids at Mayapan and Maya Highland Postclassic centers (Arnauld 1996). Also, the four places mentioned (discounting Puh, see Endnote 4) convey a quadripartite symbolism possibly more calendrical than territorial (Becquelin 1991; Coggins 1980; Mathews and Garber 2004). The fact that this is not the only example of monuments listing four entities and their geopolitical meaning should not be overstated (Tokovinine and Zender 2012, p. 61-63). However, the configuration conceived and built in Ceibal Group $\mathrm{A}$ is more elaborate and its dating to the ending of the Baktun 10 first katun is more relevant, while the Ceibal late inscriptions and architecture offer a

5. The place name Puh has been shown by Stuart (2000) to designate Teotihuacan, a city that collapsed long before 849. Puh might either refer to the new Tollan, Tula (Hidalgo, Mexico) although the date is early, or to Teotihuacan in an intentionally conservative rehearsal of the Tikal 445 commemoration ceremony (Stela 31, Martin and Grube 2000, p. 34); the previous Baktun 8 completion took place in AD 435. 
"In the days of my life." Elite activity and interactions in the Maya lowlands

number of foreign connections suggesting that local elites were involved in wide-ranging diplomatic activities.

One example is the evidence recently brought forward by Lacadena (2010a, p. 387) that on this period-ending occasion Ceibal would have imported the Venus cult and the 52-year calendar cycle from Central Mexico, both being war-related cults (see also Pascual Soto and Velasquez 2012). Such ideological imports would have prepared Ceibal to play a politico-religious role on a wider Mesoamerican scale, perhaps with the ambition of securing a specific connection with the new Tollan. Beyond Ceibal, Mexican calendar glyphs also appear on Baktun 10 stelae at Ukanal, Jimbal, and Calzada Mopan (Lacadena 2010a, p. 385). But Ceibal's foreign relationships seem to point primarily to the Northern Lowlands. Ceibal Ballcourt A-19 and sculptures dated to AD 849899 display political links to Chichen Itza, with mentions of a personage named Knife Wing also known in the Northern city (Kowalsky 1989; Smith 1982, p. 231-232; Tourtellot and González 2004, p. 69, 82).

The 849 event, which may have had repercussions among many lords, was intended to inaugurate the new Baktun with an idealized configuration for topping regional hierarchies. It occurred at Ceibal, an ancient place distinct from Tikal, Calakmul, and Caracol, but under the auspices of their dynasties, although in the latter case, indirectly through Ukanal. The local situation seems to have been relatively peaceful, as Ceibal Group A is not defensive compared to the previous Group D (Triadan 2012, p. 168). After Wat'ul's death (probably by AD 870), Ceibal remained occupied, and the moment of its complete abandonment has not yet been clearly dated (Tourtellot and Gonzalez 2004, p. 75; A. F. Chase and Chase 2004, p. 361; Inomata and Triadan 2013; Inomata et al. 2017). Wat'ul's residence (Structure A-14 or A-16) would have been ritually closed by AD 890-900 (Vega Villalobos 2011; Stela 17 is dated AD 899 so far). This attempt to reinstate the old political system, or to settle a new order, lasted two generations locally.

\section{AD 850/870-900/920: populations on the move}

The last fifty years of the long ninth century would have seen an acceleration of population movements from the East and West to the North-East and North, as well as to other regions, including the Western and Southern Highlands (Chiapas and Guatemala: see Ichon 1987, 1988). Whether or not most cities were, by then, totally deserted, is a quite different issue. Often, unknown proportions of non-elite resident populations seem to have lingered locally well into Early Postclassic times (Lamoureux-St-Hilaire et al. 2015). Last occupation components are notoriously difficult to date, and consequently the posited end of Terminal Classic ceramic phases varies from AD 920 to 1050 (Rice and Forsyth 2004, fig. 3.3). 


\section{Concomitance}

There is good evidence for a relative temporal concomitance of the Ceibal, Calakmul, Tikal, and Caracol epicenter abandonment during the 890-910 katun (Braswell et al. 2004, p. 192; A. F. Chase et Chase 2004, p. 349-350; Harrison 2000; Smith 1982; Valdés and Fahsen 2004, p. 151), with a burst of both private and public construction activity from 860 until 890 at Chichen Itza, then at Uxmal from 890 to 920 , and again at Chichen Itza where the "International style" was initiated by 900-920 (Carmean et al. 2004; Cobos et al. 2014; Hoggarth et al. 2015; Volta and Braswell 2014). Nearby Puuc cities had construction activities until 950 (Michelet et al. 2000, p. 513). The labor force for those programs could have been provided by groups migrating from the Southern Lowlands (Carmean et al. 2004, p. 442). Thus, unless this relatively tight sequence is revised through new dating, the determinant process may have been the south-to-north migration of the most prominent dynasties and affiliated houses out of paramount city palaces. Independently of their political fragmentation and weakening, those groups were still the apex of all lowland pyramidal hierarchies, and the political status quo would only have been changed by their physical displacement. The migration itself is far from being a new idea (see Chase and Chase 1982, p. 610, citing Thompson; and Cowgill 1964; also Demarest et al. 2004a, 2004b; Grube 1994b). However, recent datasets can be assembled to give it more substance, as we will see below.

During the fifth katun of Cycle 10, from AD 889 to 910, all the latest dates of stone monument dates definitely cluster (see Ebert et al. 2014, fig. 1 and 3, although with some location errors), except at Calakmul where "a few stones are even later" (Martin and Grube 2000, p. 115). Late dedications of stone monuments without inscriptions (thus undated) probably still occurred here and there in the lowlands, whereas at Chichen Itza the last inscription is dated 897 (except the isolated 9981007 inscription: Boot 2005; Krochock 1988, 1998), and Uxmal also exhibited some dated monuments into the tenth century (Sharer 1994, p. 372-373). Pending new discoveries (e.g. Caracol recently discovered Altar 26 with a conversation scene and a date corresponding to AD 884: Chase and Chase 2015), the kind of political activity, generally expressed by dated inscriptions on stelae, altars, lintels or other publicly visible stone support, was being terminated — which does not preclude that similar activities were recorded on different media, turning "public statements" into "in-group statements" (see Graham 2012, p. 428). "After complete cessation of public alliteracy production [...] alliteracy of the Postclassic period reflects the revolutionary changes occurring in the Terminal Classic political institutions, rather than ignorance of writing." (Grube 1994b, p. 340; see also Krochock 1998).

Again, further evidence might invalidate the idea but, so far, the concomitance of all three processes_-abandonment of epicenters in capitals, cessation 
"In the days of my life." Elite activity and interactions in the Maya lowlands

of erection of public monuments with dated glyphic inscriptions, and a surge of monumental construction at Chichen Itza and Uxmal-, is to be placed in the AD 870-920 interval. Those Maya agents who witnessed them were born after 820-830 in Baktun 10, and most regions of the lowlands were involved, with Uxmal apparently pre-eminently after AD 890.

\section{Group migrations: evidence still to be sifted}

Some of the group migrations could have been gradual and prepared, if not organized, by previous diplomatic action. As an example they may have been mediated in time and space by the northeastern elites of Becan, Kohunlich, and the dispersed Río Bec domains that had reached their apogee at the time. Their stelae continued to be erected in AD 869 (Río Bec Group V), in 889 and 899 (Río Bec, Pasión del Cristo: Lacadena 2007). The "Río Bec Terminal style", developed after AD 870 mainly in Groups I and V, El Porvenir, and Omelita, where huge houses were built at the core of large clusters of contemporaneous, similar, almost modular lesser houses, suggests some late immigration (Nondedeo et al. 2013, p. 382, 392, fig. 3). Becan had resumed prosperous activities mainly focused on the North (Braswell et al. 2004, p. 181; Ball 2014).

A wealth of ethnohistoric information is available on group migrations (e.g. Bullock Kreger 2010, p. 227-237), but in the Maya case there is nothing that could be applied retrospectively to the AD 870-920 interval in a south-to-north lowland direction (however, see Boot 1995, 2005; Folan et al. 2010, p. 63-64; García Campillo 2000; Rice and Rice 2007, p. 158-159). Trends towards mobility and migration during the Epiclassic in Mesoamerica have been recently discussed and conceptualized (Nelson et al. 2014, p. 174-175). Maya Classic epigraphic evidence does point to the mobility of a few dynasties or dynastic splinters that shifted residence from city to city taking their glyph emblems with them, the best-known being the cases of the Kaanul from Dzibanche to Calakmul (Martin 2005), and the Mutul from Tikal to Dos Pilas and adjacent regions (Bíró 2011a, 2011b; Gronemeyer 2012, p. 14; see also Grube 1994b, p. 326, 335, and Price et al. 2014, p. 45; note that sajal and other Western titles exist as early as the eight century at Xcalumkin in the Puuc: Jackson 2005, 2013). Current discussions of titles (Tokovinine and Zender 2012, p. 63-65) and territorial conceptions tend to question the spatial stability of social houses rooted in one ancestral place, even though this would have been the idealized template (Houston and Martin 2016, p. 449-450; Manahan 2004; McAnany 1995). In any case, the action of house abandonment should not be overstated as not all migrating groups went as far as the Puuc region (e.g. from Motul to Tayasal: Tokovinine and Zender 2012, p. 56); some may have left household members as guardians on the spot, and people may have periodically visited their former houses (Navarro-Farr et al. 2008). 
Archaeologically, "closure" or "abandonment" rituals retrieved as on-floor deposits are the primary evidence for residential mobility (Adams et al. 2004, p. 337-338; A. F. Chase and Chase 2004, p. 352; Navarro-Farr et al. 2008; Kunen et al. 2002; Lamoureux-Saint-Hilaire et al. 2015; Mock 1998; Stanton et al. 2008; Zralka 2008, p. 174, among others). Although firmly assigned to the Terminal Classic phase, those features have not been quantified subphase by subphase. They are therefore difficult to date precisely within the time interval. Those deposits are now better distinguished from on-floor de facto deposits (A. F. Chase and Chase 2004), or so-called "squatter reoccupations", by a number of traits such as the presence of human bones and even reopened burials, suggestive of the last activities of emigrants paying respect to ancestors buried beneath the dwellings, and possibly taking relics with them (Barrientos et al. 2014).

Other archaeological evidence includes intrusive dwelling morphology and ceramics (Rice and Rice 2007), and massive shifts in residential zones (see Demarest et al. 2014 for Cancuen; Garrison and Dunning 2009 for San Bartolo-Xultun; Rice and Rice 1990, p. 134-135 for the Petén Lakes region; see also above, section 4). Strontium isotope determinations of origins have been obtained on buried individuals (e.g. Freiwald 2011, 2013); however the chronological resolution is insufficient (but see Hoggarth et al. 2014). Abandonment processes and massive population movements differed from one region to another, and followed different rhythms, which are still one of the major issues in understanding the Terminal Classic period. While the Petexbatun hinterlands appear to have been rapidly deserted and never really reoccupied (Eberl 2014; O’Mansky 2014; O’Mansky and Dunning 2004), the process seems both more gradual and later at Naachtun (Sion 2016) or at El Peru-Waka' (Marken 2011). We are far from being able to assess any acceleration of mobility from AD 850 to 920 but, at least, the issues at stake and the methodologies to be implemented are now clearer.

\section{Group migrations to the North: circumstances and incentives}

The long ninth century's period of prosperity and the intensity of exchanges must have reinforced the many links woven by houses over the lowlands, enhancing their propensity to migrate to new places where they already had binding ties. Group resettlement would have been facilitated in Uxmal by its many reservoirs, and also in Chichen Itza, a pilgrimage center famed for its cenotes with abundant water resources. Uxmal and Chichen Itza appear to have been allied, at least in K'ak'upakal's time (Cobos 2010; Cobos et al. 2014; Ringle and Bey 2004; Stanton and Gallareta 2001), providing attractive conditions for migrants from regions strained by decades of conflicts and threats. 
"In the days of my life." Elite activity and interactions in the Maya lowlands

Indeed, on the basis of the sequence of events and processes developed in the present study, several powerful incentives may be listed to explain the migrations of the most important Southern houses to the North. Prestigious overlords K'ak'upakal and Cha'ak, who reigned during the AD 870-920 interval at Chichen Itza and Uxmal respectively, oversaw many rituals and commissioned numerous buildings and stone monuments, representing the emergence of a revival of $k^{\prime}$ uhul ajaw institutions in new locations (Baudez and Latsanopoulos 2010, p. 5-6; Cobos 2011; Grube 1994b; Kowalsky 1987), after many diplomatic attempts to redefine hegemonies in the Southern Lowlands. Before and after Uxmal, Chichen Itza, as a prosperous pilgrimage center, a long-distance exchange hub with Veracruz and Central Mexico, and a capital doted with innovative political and military institutions (Baudez and Latsanopoulos 2010; Cobos 2010; Krochock 1988, 1998; Ringle 2004; Ringle and Bey 2009), heralded a new period of order and authority that must have been welcomed. At last, there was a royal court for the Southern lords to stay in, and a cenote that probably had a long tradition of worship for obtaining good rainfall (Cobos et al. 2014; Moyes et al. 2009; Tozzer 1957).

\section{Aftermath}

From AD 920 to 1050 , available archaeological datasets bearing on the occupation rate of residential zones in most Lowlands Maya cities - apart from the North (see Andrews et al. 2003, p. 151) —are weak and not very reliable $^{6}$. Lamanai, Nohmul, Caracol, almost the entire coast of Belize, many cities of southeastern Petén, as well as Nakum, the well urbanized Petén Lakes region, El Zotz, Becan, and Kohunlich, were still occupied (Aimers 2007; Graham 2004; Laporte 2004; Nalda 2004; Pendergast 1985; Rice and Rice 1990; Rice et al. 1998; Zralka 2008). A remnant population is attested at Tikal until AD 1100 thanks to its water reservoirs (Grazioso and Scarborough 2013, p. $262-$ 263; Valdés and Fahsen 2004, p. 153). But in other places it may be difficult to distinguish the last occupation from the occasional visits made by commoners living dispersed in the hinterlands. Inscribed monuments were no longer erected, and masonry houses probably no longer built.

6. Zaro and Houk (2012, p. 143-144) discuss "a tenth century component"-i.e. the persistence of a reduced presence of elite and/or commoners in a number of cities - in terms of long-standing disagreements about ceramic chronologies. They also rightly raise the question of "how ceramic chronology affects models of political history" (p. 145). Given the current costs of research, one might hesitate before investing in dating this tenthcentury component - especially considering the radiocarbon difficulties, i.e. the 790-880 and 900-950 plateau in curves (Yaeger and Hodell 2008, p. 203-204). However, the stake is no less than documenting the Maya demographic trends just before the worst drought period (AD 1020-1100: Kennett et al. 2012). 


\section{Discussion and conclusion}

We have gathered as much dated information as possible for the Maya Lowland Terminal Classic period to unfold events and processes along fifty-year time units, each corresponding to two sequential human generations. Documented variables include stone monument erection, monumental architecture construction, the presence/absence of a resident population, and warfare, which together produce a picture of the conditions in which Maya agents were immersed from AD 760 to 920, and the circumstances of which they were probably aware. In such a context, we have attempted to trace their actions along two lines: diplomacy and mobility. The former is in good part illustrated by the long-known content of monument carvings, whether iconographic or epigraphic. The latter has only received attention in the last decade and is still partly hypothetical, although incipient evidence is rapidly accumulating. Taken together, diplomacy and mobility provide a panorama of what Terminal Classic agents were coping with, relying on their parents' experience, making decisions and in turn, providing directions to their own children. This proposal provides a new mode of organizing datasets transversally from many sites throughout the long ninth century following the guidelines of specific (emic) agency forms. The forms we consider to be prevalent, alliance making and mobility, are closely tied to the dynamics of the large social groups emerging in those times of declining kingship. Other agencies might also be considered, e.g. mainly in the politico-economic realm of tributes (see Graham 2006) and market networks.

The first objective of what may be seen as an experiment is to show its feasibility. In spite of limited time resolution, the evidence is enough to indicate marked changes in agency conditions from AD 760 to 920. People migrating North by 890-910 belonged to the fifth and sixth generations after those who would have experienced Cancuen's violent ending (AD 800, Figure 2). By $\mathrm{AD} 830$, first and second-generation leaders had a different perspective to those in 780, seeing new opportunities for alliances after the demise of the Western kingdoms. In turn, by 870 , the third and fourth generations witnessed the reconfiguration of many hegemonies and hierarchies throughout the lowlands, with subsequent changes in ranking and tribute systems. Around 900-920, the ending of Tikal, Calakmul, and Caracol supremacy, marked by the physical displacement of their latest elite groups, the emergence of Uxmal and Chichen Itza hegemony, and the persistent vitality of the Petén Lake region, altered the perceptions of the aging fifth-generation, and offered what seemed to be a new world to the sixth generation.

The generational sequence does not outline direct correlations between drought, political collapse and city abandonment, at least before AD 920, even though they certainly existed. This is due, first, to our broad spatial scale that obscures local impact, and, second, to the variables and agency types we selected that do 
"In the days of my life." Elite activity and interactions in the Maya lowlands

not make the correlations salient (see Iannone et al. 2014, p. 52). The archaeological, epigraphic, and iconographic proxies used in the study do not imply a direct connection to droughts. Maya agents, who left large masonry residences and carved monuments, belonged to powerful houses able to compensate, at least in part, the lowering returns from basic staples due to bad years - even though such decreases must have slowed down all activities. Non-affiliated commoners certainly suffered more, but their dispersed settlements close to aguadas and lakes have yet to be surveyed and dated on the same time scale as their urban counterparts (Rice and Rice 1990). The impact of worsening climatic conditions on the diverse Maya societies is still poorly understood.

A third result confirms that changes in hegemonic hierarchies occurred at the expense of the Eastern cities - mainly Calakmul, Tikal, Naranjo, and Caracol-whose supremacy covered a large part of what Dunning calls the "elevated interior regions" (Dunning et al. 2012). Therefore, the political transformation affected areas that overlapped with regions vulnerable to shortages in water resources and locations far from the new trading routes (Turner and Sabloff 2012). This model does not suggest the primacy of one cause over another, but, instead, underlines the interconnection of different spatial and social processes within the same polities, to be measured along one time scale.

After AD 920, and entering into the Early Postclassic period until 1100, paleoclimatic sequences indicate that climatic conditions severely worsened (Hodell et al. 2005; Hoggarth et al. 2015; Kennett et al. 2012; Medina-Elizade et al. 2010), and numerous paleoenvironmental sequences point to the abandonment of agricultural practices across the lowlands (Galop et al. 2004; Islebe et al. 1996; Leyden 2002; but see Brenner et al. 2002, p. 148). It has long been suggested that a plausible demographic collapse would have occurred during the Terminal Classic period from AD 830 to 950 (Culbert 1988). However, with the exception of the Petexbatun region, rather than rapid and complete urban desertion in the long ninth century (AD 760-920) this shows multi-scale patterns of urban occupation, mobility, and activity that still need to be explored in greater detail. The sequence of this long century suggests that, whereas "compression" and "contraction" were already threatening parts of Maya societies, a real demographic collapse did not occur until the Early Postclassic period, well after AD 920-950. This later moment corresponds to the "dark age" of Andrews et al. 2003; or the hypothetical "gap" of Nakum (Zralka and Hermes 2012, p. 176). Still to be established, this "second wave" (Hoggarth et al. 2015) would account for the non-recovery of Maya societies after the Terminal Classic collapse (the enigma posited by Webster 2014, p. 338-339; see also Manahan 2004, p. 108). Apart from a few sectors such as the Petén Lakes region, urbanization did not resume in the Petén Lowlands before AD 1200. There is certainly much to be observed and understood through the building of precise generational 
chronologies, which improve dating precision and time scale resolution and allow us to evaluate the conditions of past collective action.*

* Manuscrit reçu en mai 2015, accepté pour publication en octobre 2015.

This article is part of the Special issue Measures and textures of time among the Maya: the said, the written, and the lived.

Acknowledgements - We thank Valentina Vapnarsky and Aurore Monod Becquelin for encouraging us in furthering and formalize this piece of bibliographical horizontal digging (although certainly not exhaustive), Dominique Michelet for his support, Liz Graham, Nancy Gonlin, Arthur Demarest, Julien Sion, Julien Hiquet, Rafael Cobos, and two anonymous reviewers for their advice and comments. All errors, however, are our responsibility. We are very grateful to Krystyna Horko who carefully revised style and syntax.

\section{References cited}

Adams Richard E.W., H. R. Robichaux, Fred Valdez Jr., Brett A. Houk and Ruth Mathews 2004 "Transformation, periodicity, and urban development in the Three Rivers Region", in Arthur A. Demarest, Prudence M. Rice and Don. S. Rice (eds.), The Terminal Classic in the Maya Lowlands: Collapse, Transition, and Transformation, University of Colorado Press, Boulder, p. 324-341.

Aimers James J.

2007 "What Maya Collapse? Terminal Classic Variation in the Maya Lowlands", Journal of Archaeological Resarch, 15, p. 329-377.

Aimers James and Gyles IAnNONE

2014 "The Dynamics of Ancient Maya Developmental History" in Gyles Iannone (ed.), The Great Maya Droughts in Cultural Context. Case Studies in Resilience and Vulnerability, University Press of Colorado, Boulder, p. 21-49.

Andrews Anthony P., E. Wyllys Andrews and Fernando Robles Castellanos

2003 "The Northern maya collapse and its aftermath", Ancient Mesoamerica, 14 (1), p. 151-156.

Andrews E. Wyllys, V. and B. William Fash

1992 "Continuity and Change in a Royal Maya Residential Complex at Copán", Ancient Mesoamerica, 3, p. 63-88.

ANDrieu Chloé

2009 Outils mayas : distribution et production du silex et de l'obsidienne dans les Basses Terres, thèse de doctorat, Université Paris Ouest Nanterre La Défense.

Andrieu Chloé, Edna Rodas and Luis F. Luin

2014 "The Values of Classic Maya Jade: A Reanalysis of Cancuen's Jade Workshop", Ancient Mesoamerica, 25, p. 141-164.

ANDRIEu Chloé and Julien Sion

In press "En un cruce de camino: los intercambios en Naachtun vistos desde el análisis del material lítico", in Philippe Nondédéo and Dominique Michelet (eds.), 
"In the days of my life." Elite activity and interactions in the Maya lowlands

Naachtun-Uxul en el contexto de las tierras bajas mayas y más allá, Centros de Estudios Maya, Mexico.

Arnauld Marie Charlotte

1996 "De Nacxit a Rabinal Achi: Estados territoriales en formación en las tierras altas mayas (Postclásico)", Investigadores de la Cultura Maya 3, Publicaciones de la Universidad de Campeche, Mexico, t. 2, p. 231-268.

2012 "Neighborhoods and Intermediate Units of Spatial and Social Analysis in Ancient Mesoamerica", in Marie Charlotte Arnauld, Linda R. Manzanilla and Michael E. Smith (eds.), The Neighborhood as a Social and Spatial Unit in Mesoamerican Cities, University of Arizona Press, Tucson, p. 352-375.

2013 "Fluctuating Cities in the Classic Maya Lowlands: Dynamics of Kings and Farmers" Paper presented at the 18th Wayeb European Maya Conference, Post-Apocalypto: Crises and resiliences in the Maya World, Brussels.

In preparation "Contraction. Maya Social transformation through the Classic-toPostclassic transition".

Arnauld Marie Charlotte and Alfonso LaCADENA

2004 "Asentar su autoridad: Banquetas en el Grupo B de Río Bec (Campeche, México)", Journal de la Société des américanistes, 90-91, p. 203-222.

Arnauld Marie Charlotte, Eva Lemonnier, Mélanie Forné, Didier Galop and JeanPaul Metailie

2013a "The Rise and Fall of a Secondary Polity: La Joyanca (Guatemala)", in Marie Charlotte Arnauld and Alain Breton (eds.), Millenary Maya Societies: Past Crises and Resilience. Sociedades mayas milenarias: crisis del pasado y resiliencia, http://www.mesoweb.com/articles/title.html, p. 148-168.

Arnauld Marie Charlotte, Eva Lemonnier, Mélanie Forné, Erick Ponciano A., Julien Sion and Didier Galop

2013b "Early to Late Classic Population Mobility in La Joyanca, Northwestern Petén, Guatemala", Paper presented at the symposium "Population mobility in the hinterland of Maya cities", 78th Society for American Archaeology, Annual Meeting, Honolulu.

Arnauld Marie Charlotte, Eva Lemonnier and Mélanie Forné

2014a "Maya residential architecture, mobility and the Terminal Classic abandonment of lowland urban settlements", paper presented at the SAA 79th Annual Meeting, Austin, Texas, in Marie Charlotte Arnauld, Chris Beekman and Gregory Pereira (eds.), Ancient Mesoamerican cities: populations on the move University Press of Colorado (in preparation).

Arnauld Marie Charlotte, Dominique Michelet and Philippe Nondédéo

2013c "Living Together in Río Bec Houses: co-residence, rank and alliance", Ancient Mesoamerica, 24 (2), p. 469-493.

Arnauld Marie Charlotte, Dominique Michelet, Chloé Andrieu, Alfonso Lacadena, Eva Lemonnier, Boris Vannière, Philippe Nondédéo and JuliePAtrois

2014 b "Río Bec. Des grandes maisons et des récoltes", Journal de la Société des américanistes, 100 (2), p. 107-144.

ARnAuld Marie Charlotte and Philippe NondÉDÉO

2010 "Río Bec between the Central and the Northern Lowlands", in Laura van Broekhoven, René Valencia Rivera, Benjamin Vis and Frauke Sachse (eds.), 
The Maya and Their Neighbours: Internal and External Contacts through Time. Proceedings of the 10th European Maya Conference, Leiden, December 9-10, 2005, Acta Mesoamericana, 22, Verlag Anton Saurwein, Markt Schwaben, p. 44-59.

BALl Joseph W.

2014 "Rethinking the Becán Ceramic Sequence-Disjunctions, Continuities, Segmentation, and Chronology", Latin American Antiquity, 25 (4), p. 427-448.

Barrientos Isaac, Julien Sion, Chloé Andrieu, Daniel Salazar and Julio Cotom

2014 "Evidencias de reingreso a los espacios sepulcrales en grupos habitacionales del Clasico tardio-Terminal en Naachtun, Petén, Guatemala", XXVIII Simposio de Investigaciones Arqueológicas de Guatemala (in press).

BARRIENTOS Tomas

2014 The Royal Palace of Cancuén: The Structure of Lowland Maya Architecture and Politics at the End of the Late Classic Period, Ph.D. dissertation, Department of Anthropology, Vanderbilt University, Nashville.

Barrientos Tomás, Moisés Arriaza, Blanca Mijangos, Adriana Linares, Claudia Quintanilla and Silvia Alvarado

2006 "Excavaciones en la Estructura L7-27 de Cancuen: Temporada 2005", in Tomas Barrientos, Arthur A. Demarest, Claudia Quintanilla and Luis F. Luin (eds.), Proyecto Arqueológico Cancuen, Informe de Temporada 2004-2005, Universidad de Vanderbilt, Universidad del Valle de Guatemala. Informe entregado a la Dirección General del Patrimonio Cultural y Natural. Guatemala, p. 259-314.

Baudez Claude F. and Nicolas Latsanopoulos

2010 "Political Structure, Military Training and Ideology at Chichen Itza", Ancient Mesoamerica, 21 (1), p. 1-20.

BaILEY Geoff

2007 "Time perspectives, palimpsests and the archaeology of time", Journal of Anthropological Archaeology, 26, p. 198-223.

BECK Robin A. (ed.)

2007 The Durable House: House Society Models in Archaeology, Occasional Paper No. 35, Center for Archaeological Investigations, Southern Illinois University, Carbondale.

BeCQuelin Pierre

1991 "Les quatre directions du monde maya", in Alain Breton, Jean-Pierre Berthe and Sylvie Lecoin (éd.), Vingt études sur le Mexique et le Guatemala, Presses Universitaires du Mirail, Toulouse, p. 35-46.

BEY III G.J.

2006 "Changing archaeological perspectives on the northern Maya lowlands", in Jennifer P. Mathews and Bethany A. Morrison (eds.), Lifeways in the Northern Maya Lowlands: New Approaches to Archaeology in the Yucatán Peninsula, University of Arizona Press, Tucson, p. 13-37.

BIRO Peter

2011a The Classic Maya Western Region: A History. British Archaeological Reports International Series S2308, Hadrian Books, Oxford, England.

2011b "Politics in the Western Maya Region (I): / Ajawlel and Ch'e'n", Estudios de Cultura Maya, XXXVIII, p. 41-73. 
"In the days of my life." Elite activity and interactions in the Maya lowlands

2012 "Politics in the Western Maya Region (II): Emblem Glyphs", Estudios de Cultura Maya, XXXIX, p. 31-66.

2013 "Politics in the Western Maya region (III): The Royal and the Non-Royal Elite", Estudios de Cultura Maya, XL, p. 78-96.

Bishop Ronald L., Erin L. Sears and M. James Blackman

2005 “A Través del Río del Cambio", Estudios de Cultura Maya, XXVI, p. 17-40.

Bishop Ronald L., M. James Blackman, Erin L. Sears and Wiliam J. Folan

2006 “Observaciones iniciales sobre el consumo de la cerámica de Champóton”, Los Investigadores de la Cultura Maya, 14 (1), p. 137-145.

Bоот Erik

1995 “Kan Ek' at Chich'én Itsá. A quest into a possible Itsá heartland in the Central Petén”, Yumtzilob, 7 (4), p. 330-340.

2005 Continuity and change in text and image at Chichén Itzá, Yucatán, Mexico. A study of the Inscriptions, Iconography, and Architecture at a Late Classic to Early Postclassic Maya site, CNWS Publications, Leiden.

Braswell Geoffrey E., Joel D. Gunn, Maria del Rosario Dominguez, William L. Folan, Laraine A. Flecher, Abel Morales Lopez and Michael D. Glascock

2004 "Defining the Terminal Classic at Calakmul, Campeche" in Arthur A. Demarest, Prudence M. Rice and Don. S. Rice (eds.), The Terminal Classic in the Maya Lowlands: Collapse, Transition, and Transformation, University of Colorado Press, Boulder, p. 162-194.

Braswell Geoffrey E. and Michael D. Glascock

2003 "The Emergence of Market Economies in the Ancient Maya Worlds: Obsidian Exchange for Terminal Classic Yucatan, Mexico", in Michael D. Glascock (ed.), Geochemical Evidence for Long Distance Exchange, Bergin and Garvey, Westport, p. 33-52.

Brenner Mark, Michael F. Rosenmeier, David A. Hodell and Jason H. Curtis

2002 "Paleolimnology of the Maya Lowlands. Long-term perspectives on interactions among climate, environment, and humans", Ancient Mesoamerica, 13 (1), p. 141-157.

Bullock Kreger Meggan M.

2010 Urban Population Dynamics in a Preindustrial New World City: Morbidity, Mortality, and Immigration in Postclassic Cholula, Ph.D., The Pennsylvania State University, University Park.

Carmean Kelli, Nicholas Dunning and Jeff Karl Kowalski

2004 "High times in the Hill Country. A perspective from the Terminal Classic Puuc region", in Arthur A. Demarest, Prudence M. Rice and Don. S. Rice (eds.), The Terminal Classic in the Maya Lowlands: Collapse, Transition, and Transformation, University of Colorado Press, Boulder, p. 424-449.

Carlsten Robert S. and Martin Prechtel

1991 "The flowering of the dead", Man, New Series, 26 (1), p. 23-42.

CARsten Janet and Stephen Hugh-Jones

1995 "Introduction", in Jane Carsten and Stephen Hugh-Jones (eds.), About the House: Lévi-Strauss and Beyond, Cambridge University Press, Cambridge, p. 1-46. 
CASEs Ignacio and Philippe NondÉDÉo

2014 "El uso del tiempo en la narrativa de Naachtun del periodo Clásico", Paper presented at the Colloque Mesures et textures du temps chez les Mayas: le dit, l'écrit et le vécu, musée du quai Branly, 8-10 octobre 2014.

Chase Arlen F.

1985 "Troubled Times: The Archaeology and Iconography of the Terminal Classic Southern Lowland Maya" in Virgina M. Fields, Merle Greene Robertson Gen (eds.), Fifth Palenque Round Table, PARI, San Francisco, p. 103-114.

1992 "Elites and the Changing Organization of Classic Maya Society", in Diane and Arlen Chase (eds.), Mesoamerican Elites, University of Okalahoma Press, Norman, Oklahoma, p. 30-49.

Chase Arlen F. and Diane Z. CHASE

2004 "Terminal Classic Status-Linked Ceramics and the Maya 'Collapse': De Facto refuse at Caracol, Belize”, in Arthur A. Demarest, Prudence M. Rice and Don. S. Rice (eds.), The Terminal Classic in the Maya Lowlands: Collapse, Transition, and Transformation, University of Colorado Press, Boulder, p. 342-366.

2005 "Contextualizing the Collapse: Hegemony and Terminal Classic Ceramics from Caracol, Belize", in Sandra L. López Varela and Antonia E. Foias (eds.), Geographies of Power: Understanding the Nature of Terminal Classic Pottery in the Maya Lowlands, BAR International Series 1447, British Archaeological Reports, Oxford, p. 73-91.

2012 "Belize red ceramics and their implications for trade and exchange in the eastern Maya lowlands", in John Morris, Jaime Awe, George Thompson and Melissa Badillo (eds.), Research Reports in Belizean Archaeology, vol. 9, NICH, Institute of Archaeology, Belmopan, p. 3-14.

2015 "A new Terminal Classic Carved Altar from Caracol, Belize”, Mexicon, 37 (2), p. 47-49.

Chase Arlen F., Diane Z. Chase and Michael E. Smith

2009 "States and Empires in Ancient Mesoamerica", Ancient Mesoamerica, 20 (2), p. 175-182.

Chase Arlen F., Lisa J. Lucero, Vernon L. Scarborough, Diane Z. Chase, Rafael Cobos, Nicholas P. Dunning, Scott L. Fedick, Vilma Fialko, Joel D. Gunn, Michelle Hegmon, Gyles Iannone, David L. Lentz and Rodrigo Liendo

2014 "Tropical Landscapes and the Ancient Maya: Diversity in Time and Space", in Arlen Chase and Vernon Scarborough (eds.), The Resilience and Vulnerability of Ancient Landscapes: Transforming Maya Archaeology through IHOPE, AP3A Papers, vol. 24, American Anthropological Association, Arlington, p. 11-29.

Chase Diane Z. and Arlen F. Chase

1982 "Yucatec Influence in Terminal Classic Northern Belize", American Antiquity, 47 (3), p. 596-614.

2003 "Texts and contexts in Maya Warfare: A Brief Consideration of Epigraphy and Archaeology at Caracol, Belize" in M. Kathryn Brown and Travis W. Stanton (eds.), Ancient Mesoamerican Warfare, Alta Mira Press, Walnut Creek, p. 171-188.

2004 Archaeological Perspectives on Classic Maya Social Organization from Caracol, Belize, Ancient Mesoamerica, 15 (1), p. 139-147. 
"In the days of my life." Elite activity and interactions in the Maya lowlands

2014 Path Dependency in Rise and Denouement of a Classic Maya City: The Case of Caracol, Belize, in Arlen Chase and Vernon Scarborough (eds.), The Resilience and Vulnerability of Ancient Landscapes: Transforming Maya Archaeology through IHOPE, AP3A Papers, vol. 24, American Anthropological Association, Arlington, p. 142-154.

Christie Jessica J.

1995 Maya Period Ending Ceremonies: Re-starting time and the cosmos to assure survival of the Maya world, Ph.D. dissertation, Department of Anthropology, University of Texas, Austin.

2005 "The Stela as a Cultural Symbol in Classic and Contemporary Maya Societies", Ancient Mesoamerica, 16, p. 277-289.

Christie Jessica J. (ed.)

2003 Maya Palaces and Elite Residences. An Interdisciplinary Approach, University of Texas Press, Austin.

Cuidad Ruiz Andrés, Alfonso Lacadena, Jesús Adanez Pavon and Maria Josefa Iglesias PONCE DE LEON

2013 "Crisis y supervivencia en Machaquilá, Petén, Guatemala", in Marie Charlotte Arnauld and Alain Breton (eds.), Millenary Maya Societies, Past Crisis and Resilience, Mesoweb Publications, http://www.mesoweb.com/articles/title.html, Coвos Rafael p. 73-91.

2010 "Más allá del centro de Yucatán: reconstruyendo el dominio territorial de Chichén Itzá en las tierras bajas mayas del norte", in Edith Ortiz Díaz (ed.), Lugar, espacio y paisaje en Mesoamérica y otras áreas culturales, VI Coloquio Pedro Bosch Gimpera, Instituto de Investigaciones Antropológicas, UNAM Mexico, p. 333-348.

2011 "Multepal or Centralized Kingship? New Evidence on Governmental Organization at Chichen Itza" in Jeff Karl Kowalski and Cynthia KristanGraham (eds.), Twin Tollans. Chichen Itza, Tula, and the Epiclassic to Early Postclassic Mesoamerican World, Dumbarton Oaks, Washington, p. 249-268.

Cobos Rafael, Guillermo dE ANDA and Roberto Garcia Moll

2014 "Ancient climate and archaeology: Uxmal, Chichén Itzá, and their collapse at the end of the Terminal Classic period", in Arlen Chase and Vernon Scarborough (eds.), The Resilience and Vulnerability of Ancient Landscapes: Transforming Maya Archaeology through IHOPE, Archaeological Papers of the American Anthropological Association, 24, Washington, D.C. p. 56-71.

Coggins Clemency

1980 "The Shape of time: Some Political implications of a Four-part Figure", American Antiquity, 45 (4), p. 727-739.

1990 "The birth of the Baktun at Tikal and Seibal", in Flora S. Clancy and Peter D. Harrison (eds.), Vision and Revision in Maya Studies, University of New Mexico press, Albuquerque, p. 79-97.

Cowgill George L.

1964 "The end of Classic Maya culture: A review of recent evidence", in Graham J. A. (ed.), Ancient Mesoamerica: Selected Readings, Peek Publications, Palo Alto, CA, p. 189-203. 
Cowgill George L.

1975 "On causes and consequences of ancient and moderne population changes", American Anthropologist, 77 (3), p. 505-525.

2015 "We need better chronologies: Progress in getting them", Latin American Antiquity, 26 (1), p. 26-29.

Cucina Andreas (ed.)

2015 Archaeology and Bioarchaeology of Population Movement among the Prehispanic Maya. Springer, Cham, Heidelberg, New York, Dordrecht, London.

Culbert T. Patrick

1988 "The Collapse of Classic Maya Civilization", in Norman Yoffee and George L. Cowgill (eds.), The Collapse of Ancient States and Civilizations, University of Arizona Press, Tucson, p. 69-101.

Demarest Arthur A.

2004 "After the Maelstrom: The Classic Maya Collapse and the Terminal Classic in the Western Peten", in Arthur A. Demarest, Prudence M. Rice and Don S. Rice, The Terminal Classic in Maya Lowlands: Collapse, Transition, and Transformation, University Press of Colorado, Boulder, p. 102-124.

2006 The Petexbatun Regional Archaeological Project: A Multidisciplinary Study of the Maya Collapse. Vanderbilt Institute of Mesoamerican Archaeology Monograph Series, vol. 1, Vanderbilt University Press, Nashville, TN.

2013a "Ideological Pathways to Economic Exchange: Religion, Economy, and Legitimation at the Classic Maya Royal Capital of Cancuén", Latin American Antiquity, 24, p. 371-402.

2013 b "The Collapse of the Classic Maya Kingdoms of Southwestern Petén: Implications for the end of Classic Maya Civilization", in Marie Charlotte Arnauld and Alain Breton, Millenary Maya Societies, Past Crisis and Resilience, Mesoweb Publications, http://www.mesoweb.com/articles/title.html, p. 22-48.

2014 "Collapse and Non-Recovery in the "Wet Zone": The Aborted Economic and Political Transition at the Far Southern Border of the Classic Maya World", in Gyles Iannone (ed.), The Great Maya Droughts in Cultural Context: Case Studies in Resilience and Vulnerability, University Press of Colorado, Boulder, p. 177-206.

Demarest Arthur A., Chloé Andrieu, Paola Torres, Mélanie Forné, Tomas Barrientos and Marc Wolf

2014 "Economy, Exchange, and Power: New Evidence from the Late Classic Maya Port City of Cancuen", Ancient Mesoamerica, 25, p. 87-219.

Demarest Arthur A. and Horacio Martinez

2010 "El intento infructuoso a una transición Clásico-Postclásico en Cancuén”, in Barbara Arroyo, A. Linares Palma and Lorena Paiz Aragon (eds.), XXIV Simposio de Investigaciones Arqueológicas en Guatemala, 2009, Museo Nacional de Arqueología, Guatemala Ciudad, p. 609-620.

Demarest Arthur A., Horacio Martinez, Marc Wolf, Paola Torres, Waleska Belches, Chloé Andrieu, Luis F. Luin, Matt O'Mansky and Claudia Quintanilla

2009 "Economía interna, relaciones internacionales de Cancuén y de los sitios de su reinado", in Juan Pedro Laporte, Bárbara Arroyo and Héctor E. Mejía (eds.), XXII Simposio de Investigaciones Arqueológicas en Guatemala, 
"In the days of my life." Elite activity and interactions in the Maya lowlands

2008, Ministerio de Cultura y Deportes, Instituto de Antropología e Historia, Asociación Tikal. Guatemala, p. 655-674.

Demarest Arthur A., Prudence M. Rice and Don. S. Rice (eds.)

2004a The Terminal Classic in the Maya Lowlands: Collapse, Transition, and Transformation, University of Colorado Press, Boulder.

2004b "The Terminal Classic in the Maya Lowlands. Assessing Collapses, Terminations, and Transformations", in Arthur A. Demarest, Prudence M. Rice and Don. S. Rice (eds.), University of Colorado Press, Boulder, p. 545-572.

Demarest Arthur, Juan Antonio Valdez, Héctor Escobedo, Federico Fahsen, Tomás BARRIENTOS and Horacio MARTINEZ

2012 “25 años de proyectos regionales en el valle del río La Pasión: una visión general de las investigaciones, resultados y perspectivas sobre los últimos siglos de una gran ruta maya", in Bárbara Arroyo, Lorena Paiz Aragón and Héctor E Mejía (eds.), XXV Simposio de Investigaciones Arqueológicas en Guatemala, 2011, Asociación Tikal, Museo Nacional de Arqueología y Etnología, Guatemala, p. 97-110.

Douglas Peter M. J., Mark Pagania, Marcello A. Canuto, Mark Brenner, David A. Hodell, Timothy I. Eglintone and Jason H. Curtis

2015 "Drought, agricultural adaptation, and sociopolitical collapse in the Maya Lowlands", Proceedings of the National Academy of Sciences, 112 (18), p. 5607-5612.

Dunning Nicholas P., Timothy P. Beach and Sheryl Luzzadder-Beach

2012 "Kax and kol: collapse and resilience in lowland Maya civilization", Proceedings of the National Academy of Sciences, 109 (10), p. 3652-3657.

EBERL Markus

2014 Community and Difference, Change in Late Classic Maya Villages of the Petexbatun Region, Vanderbilt Institute of Mesoamerican Archaeology, Arthur A. Demarest Series Editor, vol. 8, Vanderbilt University Press, Nashville.

Ebert Claire E., Brendan J. Culleton, Jaime J. Awe and Douglas J. Kennett

2016 "AMS 14C Dating of Preclassic to Classic Period Household Construction in the Ancient Maya Community of Cahal Pech, Belize", Radiocarbon, Available on CJO 2016 doi: 10.1017/RDC.2015.7

Ebert Claire E., Keith M. Prufer and Douglas J. Kennett

2014 "Maya Monuments and Spatial Statistics: A Gis-Based Examination of the Terminal Classic Period Maya Collapse”, Ancient Mesoamerica, 25 (2), p. 337-356.

Eppich Evan Keith, Griselda Perez, Ana Lucia Arroyave, Fabiola Quiroa, Juan Carlos Melendez and Edwin Roman

2005 "Estudio Cerámico, la secuencia de la Tradición Cerámica de El Perú-Waka", in Hector Escobedo and David Freidel (eds.), Proyecto Arqueológico El Perú-Waka': Informe $n^{\circ}$ 2, Temporada 2004, Guatemala, p. 313-350.

FAHSEn Federico and Arthur A. Demarest

2001 "El papel del reino de Cancuén en la historia de las Tierras Bajas Mayas. Nuevos datos epigráficos" in Juan Pedro Laporte, Ana Claudia Monzón de Suasnávar and Bárbara Arroyo (eds.), XIV Simposio de Investigaciones Arqueológicas en 
Guatemala, 2000, Museo Nacional de Arqueología y Etnología, Guatemala, p. $999-1015$.

Fahsen Federico, Arthur A. Demarest and Luis F. Luin

2003 "Sesenta años de historia en la Escalinata Jeroglífica de Cancuén", in Juan Pedro Laporte, Bárbara Arroyo, Héctor L. Escobedo and Héctor E. Mejía (eds.), XVI Simposio de Investigaciones Arqueológicas en Guatemala, 2002, Museo Nacional de Arqueología y Etnología, Guatemala, p. 711-722.

FASH William and David STUART

1991 "Dynastic History and Cultural Evolution at Copan, Honduras", in T. Patrick Culbert (ed.), Classic Maya Political History: Hieroglyphic and Archaeological Evidence, Cambridge University Press, New York, p. 147-180.

Fash William L., E. Wyllys Andrews, V. and T. Kam Manahan

2004 "Political Decentralization, Dynastic Collapse, and the Early Postclassic in the Urban Center of Copan, Honduras", in Arthur A. Demarest, Prudence M. Rice and Don S. Rice (eds.), The Terminal Classic in the Maya Lowlands, University Press of Colorado, Boulder, p. 260-287.

FeINMAN Gary M.

2000 "Mesoamerican Political Complexity. The Corporate-Network Dimension", in Jonathan Haas (ed.), From Leaders to Rulers, Kluwer Academic/Plenum Publishers, New York, p. 151-175.

FeInMan Gary M. and Linda Nicholas

2016 "After Monte Albán in the Central Valleys of Oaxaca: A Reassessment", in Ronald K. Faulseit (ed.), Beyond Collapse: Archaeological Perspectives on Resilience, Revitalization, and Transformation in Complex Societies, Southern Illinois University, Center for Archaeological Investigations, Occasional Paper 42, Carbondale, p. 43-69.

Foias Antonia E. and Ronald L. Bishop

1997 "Changing Ceramic production and Exchange in the Petexbatun Region, Guatemala: Reconsidering the Classic Maya Collapse", Ancient Mesoamerica, 8 (2), p. 275-292.

2005 "Fine paste wares and the Terminal Classic in the Petexbatun", in Sandra L. Lopez Varela and Antonia E. Foias (eds.), Geographies of Power: Understanding the Nature of Terminal Classic Pottery in the Maya Lowlands, BAR International Series 1447, British Archaeological Reports, Oxford, p. 23-40.

2007 "Pots, Sherds, and Glyphs: Pottery Production and Exchange in the Petexbatun Polity, Petén, Guatemala", in Christopher A. Pool and George J. Bey III (eds.), Pottery Economics in Mesoamerica, Tucson: University of Arizona Press, p. 212-236.

Folan William J., A. Morales, R. Gonzalez, Maria del Rosario Dominguez, Armando Anaya, Joel D. Gunn and Kathryn Josserand

2010 "El estado regional de Calakmul, Campeche, México: descubrimientos recientes", in Antonio Benavides Castillo and Ernesto Vargas Pacheco (eds.), La península de Yucatán: investigaciones recientes y cronologias alternativas, Universidad Autónoma de Campeche, Campeche, p. 59-69. 
"In the days of my life." Elite activity and interactions in the Maya lowlands

ForNé Mélanie

2006 La cronologia cerámica de La Joyanca, Noroeste del Peten, Guatemala. BAR International Series 17, Paris.

Forné Mélanie, Silvia Alvarado and Paola Torres

2011 "Cronología cerámica en Cancuén: Historia de una ciudad del Clásico Tardío", Estudios de Cultura Maya, 26, p. 11-39.

Forné Mélanie, Chloé Andrieu, Arthur A. Demarest, Paola Torres, Claudia Quintanilla, Ronald L. Bishop and Olaf Jaime Riveron

2013 "Crisis y cambios en el Clásico Tardío: los retos económicos de una ciudad entre Tierras Altas y Tierras Bajas mayas", Mesoweb, http://www.mesoweb. com/articles/title.html

Forné Mélanie, Chloé Andrieu and Arthur Demarest

2014 "Estrategias económicas, estrategias políticas en el antiguo reinado de Cancuen, Guatemala", in Veronica Vazquez López, Rogelio Valencia Rivera and Eugenia Gutierrez (eds.), Socio-political Strategies among the Maya from the Classic Period to the Present, British Arqueological Reports, p. 33-50.

Forné Mélanie, Ronald L. Bishop, Arthur A. Demarest, M. James Blackman and Erin L. SEARS

2010 "Gris Fino, Naranja Fino: presencia temprana y fuentes de producción, el caso de Cancuén", in Bárbara Arroyo, Lorena Paiz Aragón, Adriana Linares Palma and Ana Lucía Arroyave (eds.), XXIII Simposio de Investigaciones Arqueológicas en Guatemala, 2009, Museo Nacional de Arqueología y Etnología, Guatemala, p. 1163-1182.

Fowler William R. and Marie Charlotte ARNAUld

2013 "Special Section: Noble Farmers and Weak Kings in the Classic Maya Lowlands: The Río Bec Archaeological Project, 2002-2010. Introduction", Ancient Mesoamerica, 24 (2), p. 343-351.

FREIWALD Carolyn

2011 "Patterns of Population Movement at Xunantunich, Cahal Pech, and Baking Pot during the Late and Terminal Classic (AD 600-900)", Research Reports in Belizean Archaeology, 8, p. 89-100.

2013 "Urban and Rural Population Movement Patterns during the Late and Terminal Classic in the Belize River Valley", paper presented in the SAA Meetings, in Honolulu in Ancient Mesoamerican cities: populations on the move Marie Charlotte Arnauld, Gregory Pereira and Christopher Beekman (eds.), (in preparation).

Galop Didier, Eva Lemonnier, Jean-Michel Carozza and Jean Pierre Metailie

2004 "Bosques, milpas, casas y aguadas de antaño", in Marie Charlotte Arnauld, Véronique Breuil-Martinez and Erick Ponciano A., La Joyanca, antigua ciudad maya del noroeste del Petén (Guatemala), CEMCA, CIRMA, Associacion Tikal, Guatemala, p. 55-71.

García Campillo José Miguel

2000 Estudio introductorio del lexico de las inscripciones de Chichén Itzá, Yucatán, Mexico, BAR International Series 831, Oxford.

GARrison Thomas G. and Nicholas P. DunNing

2009 "Settlement, environment, and politics in the San Bartolo-Xultun territory", Latin American Antiquity, 20 (4), p. 525-552. 
GiLlePsie Susan D.

2000 "Levi-Strauss. Maisons and Sociétés à Maisons", in Rosemary A. Joyce and Susan D. Gillespie (eds.), Beyond Kinship: Social and Material Reproduction In House Societies, University of Pennsylvania Press, Philadelphia, p. 23-52.

2010 "Maya memory work", Ancient Mesoamerica, 21 (2), p. 401-414.

Golden Charles and Andrew K. Scherer

2013 "Territory, Trust, Growth, and Collapse in Classic Period Maya Kingdoms", Current Anthropology, 54 (4), p. 397-435.

Golitko Mark, James Meierhoff, Gary M. Feinman and Patrick Ryan Williams

2012 "Complexities of collapse: the evidence of Maya obsidian as revealed by social network graphical analysis", Antiquity, 86 (332), p. 507-523.

GraHAm Elizabeth A.

2001 "Collapse, Conquest and Maya Survival at Lamanai, Belize", Archaeology International, 4, p. 52-56.

2004 "Lamanai reloaded: Alive and well in the Early Postclassic", in James Awe, John Morris and Sherilyne Jones (eds.), Research Reports in Belizean Archaeology Vol. 1, Institute of Archaeology, NICH, Belmopan, p. 223-241.

2006 "An Ethnicity to know", in Frauke Sachse (ed.), Maya Ethnicity. The Construction of Ethnic Identity from Preclassic to Modern Times, Acta Mesoamericana, vol. 19, Verlag Anton Saurwein, p. 109-124.

2012 "Control without controlling: Motul de San José and its environment from an Outsider's Perspective", in Antonia E. Foias and K. F. Emery (eds.), Motul de San José. Politics, History and Economy in a Classic Maya Polity, University Press of Florida, p. 419-430.

Graham John

1990 Excavations at Seibal: Monuments Sculptures and Hieroglyphic Inscriptions. Peabody Museum of Archaeology and Ethnology Memoirs, vol. 14, no. 1.

Grazioso Liwwy and Vernon Scarborough

2013 "Lo húmedo y lo seco: el manejo del agua y la construcción del paisaje en Tikal", in Marie Charlotte Arnauld and Alain Breton (eds.), Millenary Maya Societies, Past Crisis and Resilience, Mesoweb Publications, http://www. mesoweb.com/articles/title.html, p. 249-264.

Gronemeyer Sven

2012 "Statements of Identity_Emblem Glyphs in the Nexus of Political Relations", Contributions in New World Archaeology 4, p. 13-40.

Grube Nikolai

1994a "Epigraphic Research at Caracol, Belize", Studies in the Archaeology of Caracol, Belize, Monograph 7, PARI.

1994b "Hieroglyphic sources for the history of Northwestern Yucatan, Mexico, Yucatán", in Hanns J. Prem (ed.), Hidden among the Hills: Maya archaeology of the Northwest Yucatán Peninsula, Acta Mesoamericana, Verlag von Flemming, Möckmüll, Bonn, vol. 7, p. 316-358.

2000 "The city-states of the Maya", in Mogens Herman Hansen (ed.), A Comparative Study of Thirty City-State Cultures, The Royal Danish Academy of Sciences and Letters, Copenhagen, p. 547-566. 
"In the days of my life." Elite activity and interactions in the Maya lowlands

2008 "Monumentos esculpidos: epigrafía e iconografía”, in Ivan Šprajc (ed.), Reconocimientos arqueológicos en el sureste del estado de Campeche, México: 1996-2005, BAR International Series, Oxford, p. 177-231.

2013 Stars War: Increasing Conflicts in the Terminal Classic. Paper presented at the 18th European Maya Conference Symposium, Wayeb, Brussels.

Hansen Richard D., Wayne K. Howell and Stanley Guenter

2008 "Forgotten Structures, Haunted Houses, and Occupied Hearts: Ancient Perspectives and Contemporary Interpretations of Abandoned Sites and Buildings in the Mirador Basin, Guatemala", in Davis W. Stanton and Aline Magnoni (eds.), Ruins of the Past, The Use and Perception of Abandoned Structures in the Maya Lowlands, University Press of Colorado, Boulder, p. 25-64.

HARRISON Peter D.

2000 The lords of Tikal: Rulers of an Ancient Maya City, Thames and Hudson, Londres. HARrison-Buck Eleanor and Patricia A. McAnany

2013 "Terminal Classic Circular Architecture in the Sibun Valley, Belize", Ancient Mesoamerica, 24, p. 295-306.

Helmke Christophe and Dorie ReEnts-Budet

2008 "A Terminal Classic Molded-carved Ceramics Type from the Eastern Maya Lowlands", Research Reports in Belizean Archaeology, vol. 5, p. 37-49.

Hendon Julia A.

2000 "Having and Holding: Storage, Memory Knowledge and Social Relations", American Anthropologist, 102 (1), p. 42-53.

2010 Houses in a landscape. Memory and everyday life in Mesoamerica. Duke University Press, Durham.

2012 "Neighborhoods in Prehispanic Honduras: Settlement Patterns and Social Groupings within Sites or Regions", in Marie Charlotte Arnauld, Linda R. Manzanilla and Michael E. Smith (eds.), The Neighborhood as a Social and Spatial Unit in Mesoamerican Cities, University of Arizona Press, Tucson, p. 159-180.

Hermes Bernard and Gustavo Martínez

2005 "El Clásico Terminal en el área de la laguna Yaxha, Petén”, in Juan Pedro Laporte, Bárbara Arroyo and Héctor Mejía (eds.), XVIII Simposio de Investigaciones Arqueológicas en Guatemala, 2004, Museo Nacional de Arqueología y Etnología, Guatemala, p. 139-146.

HiLl Robert M.

1996 Eastern Chajoma (Cakchiquel) Political Geography: Ethnohistorical and Archaeological Contributions to the Study of a Late Postclassic Maya Highland Polity. Ancient Mesoamerica, 7 (1), p. 63-87.

Hill Robert M. II and John Monaghan

1987 Continuities in Highland Maya Social Organization: Ethnohistory in Sacapulas, Guatemala, University of Pennsylvania Press, Philadelphia.

Hodell David A., Mark Brenner and Jason H. Curtis

2005 "Terminal Classic drought in the northern Maya lowlands inferred from multiple sediment cores in Lake Chichancanab (Mexico)", Quaternary Science Reviews, 24, p. 1413-1427. 
Hoggarth Julie A., Brendan J. Culleton, Jaime J. Awe and Douglas J. Kennett

2014 "Questionning Postclassic Continuity at Baking Pot, Belize, Using Direct AMS C14 Dating of Human Burials”, Radiocarbon, 56 (3), p. 1057-1075.

Hoggarth Julie A., Sebastian F.M. Breitenbach, Brendan J. Culleton, Claire E. Ebert, Marilyn A. MAsson and Douglas J. KennetT

2015 "The political collapse of Chichén Itzá in climatic and cultural context", Global and Planetary Change (www.elsevier.com/locate/gloplacha).

Houston Stephen D.

1993 Hieroglyphs and History at Dos Pilas: Dynastic Politics of the Classic Maya, University of Texas Press, Austin.

Houston Stephen D. and Takeshi Inomata

2009 The Classic Maya, Cambridge University Press, Cambridge.

Houston Stephen D. and Simon MarTin

2016 "Through seeing stones: Maya epigraphy as a mature discipline", Antiquity, 90, p. 443-455.

Houston Stephen D. and Peter Mathews

1985 The Dynastic Sequence of Dos Pilas, Guatemala, Pre-Columbian Art Research Institute Monograph, no. 1, San Francisco.

Houston Stephen D. and David StuarT

1996 "Of Gods, Glyphs, and Kings: Divinity and Rulership among the Classic Maya", Antiquity, 70, p. 289-312.

2001 "Peopling the Classic Maya Court", in Takeshi Inomata and Stephen D. Houston (eds.), Royal courts of the Ancient Maya. Volume Two: Data and Case Studies, Westview Press, Boulder and Oxford, p. 54-83.

HRUBY Zachary X.

2006 The organization of Chipped Stone Economies at Piedras Negras, Guatemala, unpublished Ph.D., University of California Riverside, Ms.

IANNONE Gyles

2005 "The Rise and Fall of a Petty Royal Court", Latin American Antiquity, 16, p. 26-44.

2010 "Collective Memory in the frontiers: A case study from the ancient Maya center of Minanha, Belize", Ancient Mesoamerica, 21 (2), p. 353-372.

IANNONE Gyles (ed.)

2014 The Great Maya Droughts in Cultural Context. Case Studies in Resilience and Vulnerability, University Press of Colorado, Boulder.

IANNONE Gyles, Jason YAEGER and David Hodell

2014 "Chapter 3. Assessing the Great Maya droughts: Some Critical Issues", in Gyles Iannone (ed.), The Great Maya Droughts in Cultural Context. Case Studies in Resilience and Vulnerability, University Press of Colorado, Boulder, p. 51-70.

ICHON Alain

1987 “Contribution à la définition de l'Epiclassique dans les hautes terres mayas", in Memorias del Primer Congreso Internacional de Mayistas, UNAM, México, p. 175-208.

1988 "Le peuplement préhispanique", in Alain Ichon, Denise Douzant-Rosenfeld and Pierrre Usselmann, La vallée moyenne du Río Chixoy (Guatemala), 6: 
"In the days of my life." Elite activity and interactions in the Maya lowlands

Occupation préhispanique et problèmes actuels, Institut d'Ethnologie, CNRS and Editorial Piedra Santa, Paris and Guatemala, p. 53-206.

INOMATA Takeshi

2004 "The Spatial Mobility of Non-Elite Populations in Classic Maya Society and its Political Implications", in John C. Lohse and Fred Valdez Jr. (eds.), Ancient Maya Commoners, University of Texas Press, Austin, p. 175-196.

2008 Warfare and the Fall of a Fortified Center: Archaeological Investigations at Aguateca, Vanderbilt Institute of Mesoamerican Archaeology Monographs, vol. 3, Vanderbilt University Press, Nashville, TN.

InOMATA Takeshi and Daniela TRIADAN

2009 "Culture and Practice of War in Maya Society", in Axel E. Nielsen and William H. Walker (eds.), Warfare in Cultural Context. Practice, Agency and the archaeology of violence, The University of Arizona Press, Tucson, p. 56-83.

2013 "The Terminal Classic Period at Ceibal and in the Maya Lowlands", in Marie Charlotte Arnauld and Alain Breton (eds.), Millenary Maya Societies, Past Crisis and Resilience, Mesoweb Publications, p. 62-67, http://www.mesoweb. com/articles/title.html

INOMATA Takeshi and Daniela TrIADAN (eds.)

2010 Burned Palaces and Elite Residences of Aguateca: Excavations and Ceramics, University of Utah Press, Salt Lake City.

Inomata Takeshi, Daniela Triadan, Erik Ponciano, Estela Pinto, Richard E. Terry and Markus EBERL

2002 "Domestic and Political Lives of Classic Maya Elites: the Excavation of Rapidly Abandoned Structures at Aguateca, Guatemala", Latin American Antiquity, 13 (3), p. 305-330.

Inomata Takeshi, Erick M. Ponciano, Oswaldo F. Chinchilla MaZariegos, Otto Román, Véronique Breuil-Martínez and Oscar SAntos

2004 "An Unfinished Temple at the Classic Maya Center of Aguateca, Guatemala", Antiquity, 78 (302) p. 798-811.

2017 High-precision radiocarbon dating of political collapse and dynastic origins at the Maya site of Ceibal, Guatemala. Proceedings of the National Academy of Sciences, (early edition, January 2017).

Islebe Gerald A., Henry Hooghiemstra, Mark Brenner, Jason H. Curtis and David A. HODELL

1996 "A Holocene vegetation history from Lowland Guatemala", The Holocene, 6, p. 265-271.

JACKSON Sarah E.

2005 Deciphering Classic Maya Political Hierarchy: Epigraphic, Archaeological, and Ethnohistorical Perspectives on Courtly Elite, Ph.D. dissertation, Department of Anthropology, Harvard University, Cambridge, MA.

2009 "Imagining courtly communities. An Exploration of Classic Maya Experiences of Status and Identity through Painted Ceramic Vessels", Ancient Mesoamerica, 20 (1), p. 61-85.

2013 Politics of the Maya court: hierarchy and change in the Late Classic period, University of Oklahoma Press, Norman. 
JACKSON Sarah E. and David STUART

2001 "The AJ K'UHUN title. Deciphering a Classic Maya term of rank", Ancient Mesoamerica, 12, p. 217-228.

JONES Grant D.

1998 The Conquest of the Last Maya Kingdom, Stanford University Press, Stanford.

Kennett Douglas J., Sebastian F. M. Breitenbach, Valorie V. Aquino, Yemane Asmerom, Jaime Awe, James U.L. Baldini, Patrick Bartlein, Brendan J. Culleton, Claire EBERT, Christopher JAzWA, Martha J. MACRI, Norbert Marwan, Victor PolyaK, Keith M. Prufer, Harriet E. Ridley, Harald Sodemann, Bruce Winterhalder and Gerald H. HAUG

2012 "Development and Disintegration of Maya Political Systems in Response to Climate Change", Science Vol. 338, Nov. 9, p. 788-791.

KowALSKY Jeff Karl

1987 The House of the Governor: A Maya palace at Uxmal, Yucatan, Mexico, University of Okalohoma press, Norman.

1989 "Who am I among the Itza? Links between Northern Yucatan and the Western Maya Lowlands and Highlands", in Richard A. Diehl and Janet C. Berlo (eds.), Mesoamerica after the Decline of Teotihuacan, AD 700-900, Dumbarton Oaks, Washington, p. 173-185.

Квосноск Ruth

1988 The Hieroglyphic Inscriptions and Iconography of the Temple of the Four lintels and Related Monuments, Chichen Itza, Yucatán, Mexico. Unpublished M.A. Thesis, University of Texas, Austin.

1998 The Development of Political Rhetoric at Chichen Itza, Yucatán, Mexico. Ph.D. Dissertation, Southern Methodist University, Dallas.

Kunen Julie L., Mary Jo Galindo and Erin Chase

2002 "Pits and bones: identifying Maya ritual behavior in the archaeological record", Ancient Mesoamerica, 13 (2), p. 197-211.

LACADENA Alfonso

2007 Las inscripciones de Rio Bec. Paper presented at the VII Congreso Internacional de Mayistas, Mérida.

2008 "El título Lakam: evidencia epigráfica sobre la organización tributaria y militar de los reinos mayas del Clásico", Mayab, 20, p. 23-43.

2010a "Highland Mexican and Maya Intellectual Exchange in the Late Postclassic: Some Thoughts on the Origin of Shared Elements and Methods of Interaction", in Gabrielle Vail and Christine Hernández, Astronomers, Scribes, and Priests Intellectual Interchange between the Northern Maya Lowlands and Highland Mexico in the Late Postclassic Period. Dumbarton Oaks, Washington D.C. p. 383-406.

2010 b Títulos militares en los textos jeroglíficos mayas del periodo clásico, paper presented at the VIIIth Congreso de Mayistas, Mexico.

Lamoureux-Saint-Hilaire Maxime, Scott Macrae, Carmen A. McCane, Evan A. PARKER and Gyles IANNONE

2015 "The Last Groups Standing: Living Abandonment at theAncient Maya Center of Minanha, Belize", Latin American Antiquity, 26 (4), p. 550-569. 
"In the days of my life." Elite activity and interactions in the Maya lowlands

LAPORTE Juan Pedro

2004 "Terminal Classic Settlement and Polity in the Mopan Valley, Petén, Guatemala", in Arthur A. Demarest, Prudence M. Rice and Don. S. Rice (eds.), The Terminal Classic in the Maya Lowlands: Collapse, Transition, and Transformation, University of Colorado Press, Boulder, p. 195-230.

LAPORTE Juan Pedro and Héctor E. MeJía

2002 "Tras la huella del Mopan: arquitectura del Clásico Terminal y del Postclásico en el Sureste de Petén", in Juan Pedro Laporte, Héctor L. Escobedo and Bárbara Arroyo (eds.), XV Simposio de Investigaciones Arqueológicas en Guatemala, Museo Nacional de Arqueología y Etnología, Guatemala, p. 65-96.

LeCount Lisa J. and Jason YAEGER

2010 "A brief description of Xunantunich", in Lisa J. LeCount and Jason Yaeger, Classic Maya Provincial politics: Xunantunich and its hinterlands, University of Arizona Press, Tucson, p. 67-78.

LeCount Lisa J., Jason Yaeger, Richard Leventhal and Wendy Ashmore

2002 "Dating the rise and fall of Xunantunich, Belize. A late and terminal Classic Clolwnad maya center", Ancient Mesoamerica, 13 (2), p. 41-63.

LEMONNIER Eva

2009 La structure de l'habitat du site maya classique de La Joyanca dans son environnement local (Petén, Guatemala), Paris Monographs in American Archaeology 23, BAR International Series 2016, Oxford.

LEYDEN Barbara

2002 "Pollen evidence for climatic variability and cultural disturbance in the Maya Lowlands", Ancient Mesoamerica, 13, p. 85-101.

Lohse Jon C. and Fred VAldez Jr. (eds.)

2004 Ancient Maya Commoners. University of Texas Press, Austin.

LÓPEZ Austin Alfredo and Leonardo LóPEZ LuJÁN

1999 Mito y realidad de Zuyua. Serpiente Emplumada y las transformaciones mesoamericanas del Clásico al Posclásico. El Colegio de México, Fideicomiso Historia de las Américas, Fondo de Cultura Económica, México.

López Varela Sandra L.

2005 "Dynamics and Engagement in the Usumacinta River Valley and the Coastal Plains of Tabasco: Traversing Terminal Classic Hypotheses", in Sandra L. López Varela and Antonia E. Foias (eds.), Geographies of Power: Understanding the Nature of Terminal Classic Pottery in the Maya Lowlands, BAR International Series 1447, British Archaeological Reports, Oxford, p. 41-60.

Manahan T. Kam

2004 "The Way Things Fall apart. Social organization and the Classic Maya collapse of Copan”, Ancient Mesoamerica, 15, p. 107-125.

Manahan T. Kam and Marcello A. CAnuto

2009 "Bracketing the Copan Dynasty: Late Preclassic and Early Postclassic Settlements at Copan, Honduras", Latin American Antiquity, 20 (4), p. 553-580.

Marcus Joyce

1976 Emblem and State in the Classic Maya Lowlands. An Epigraphic Approach to Territorial Organization, Dumbarton Oaks, Washington. 
Marcus Joyce

2012 "Yucatán at the crossroads", in Geoffrey E. Braswell (ed.), The Ancient Maya: Reinterpreting the past, Equinox, San Diego University Press, San Diego, p. 349-371.

Marken Damien B.

2011 City and State: Urbanization, Rural Settlement and Polity in the Classic Maya Lowlands, Ph.D. dissertation, Department of Anthropology, Dedman College Southern Methodist University, Dallas.

MARMÉ Michael

2008 "Locating Linkages or Painting Bull's-Eyes around Bullet Holes? An East Asian Perspective on the Seventeenth-Century Crisis", American Historical Review, 113 (4), p. 1080-1089.

Márquez Morfín Lourdes and Patricia Hernández Espinoza

2013 "Los mayas del clásico tardío y terminal. Una propuesta acerca de la dinámica demográfica de algunos grupos mayas prehispánicos: Jaina, Palenque y Copán”, Estudios de Cultura Maya XLII, p. 53-86.

Martin Simon

2005 "Of Snakes and Bats: Shifting Identities at Calakmul”, The PARI Journal, 6 (2), p. 5-15, http://www.mesoweb.com/articles/title.html

MARTin Simon and Nikolai Grube

2008 [2000] Chronicle of the Maya Kings and Queens: Deciphering the Dynasties of the Ancient Maya. Thames and Hudson, Londres.

Martínez Gustavo and Mélanie ForNÉ

2014 “Operación IV.1: Análisis cerámico de la Temporada 2013”, in Philippe Nondédéo, Carlos Morales Aguilar, Julien Sion, Dominique Michelet and Chloé Andrieu (eds.), Proyecto Petén-Norte Naachtun 2010-2014: Informe de la cuarta temporada de campo 2013, Informe entregado al IDAEH, Guatemala, p. 483-496.

Masson Marylin A.

2002 "Introduction", in Marylin Masson et David Freidel (eds.), Ancient Maya Political Economies, Altamira Press, New York, p. 1-30.

Masson Marilyn A. and Shirley B. Mock

2004 "Ceramics and Settlement patterns at terminal Classic-Period laggoon Sites in NorthEastern Belize", in Arthur A. Demarest, Prudence M. Rice and Don. S. Rice (eds.), The Terminal Classic in the Maya Lowlands: Collapse, Transition, and Transformation, University of Colorado Press, Boulder, p. 367-401.

Mathews Jennifer P. and James F. GARBER

2004 "Models of Cosmic Order: Physical expression of sacred space among the ancient Maya", Ancient Mesoamerica, 15 (1), p. 49-59.

McAnany Patricia A.

1995 Living with the ancestors: kinship and kingship in ancient Maya society, University of Texas Press, Austin.

2013 "Mesoamerica Artisans, Ikatz, and Starcraft: Provisioning Classic Maya Royal Courts", in Kenneth G. Hirth and Joanne Pillsbury (eds.), Merchants, Markets, and Exchange in the PreColumbian World, Dumbarton Oaks, Washington (DC), p. 229-253. 
"In the days of my life." Elite activity and interactions in the Maya lowlands

McVicker Donald and Joel W. PALKA

2001 "A Maya carved shell plaque from Tula, Hidalgo, Mexico", Ancient Mesoamerica, 12 (2), p. 157-197.

Medina-Elizalde Martín, Stephen J. Burns, David W. Lea, Yemane Asmerom, Lucien von Gunten, Victor Polyak, Mathias Vuille and Ambarish Karmalkar

2010 "High resolution stalagmite climate record from the Yucatán Peninsula spanning the Maya terminal Classic period", Earth and Planetary Science Letters, 298, p. 255-262.

Michelet Dominique, Pierre Becquelin and Marie Charlotte Arnauld

2000 Mayas del Puuc. Arqueología de la región de Xculoc, Campeche, Gobierno del Estado de Campeche, Centre Français d'Etudes Mexicaines et Centraméricaines, Mexico.

Michelet Dominique, Philippe Nondédéo, Julie Patrois, Céline Gillot and Emyly GONZÁLEZ

2013 “Structure 5N2 (Groupe A): A Río Bec Paradigmatic Palace?", Ancient Mesoamerica, 24 (2), p. 415-431.

Middleton Guy D.

2012 "Nothing Lasts Forever: Environmental Discourses on the Collapse of Past Societies", Journal of Archaeological Research, 20, p. 257-307.

Mock Shirley Boteler

1997 "Monkey Business at Northern River Lagoon: A coastal-Inland Interaction Sphere in Northern Belize", Ancient Mesoamerica, 8 (2), p. 165-183.

2005 "Pushing the Limits: Late to Terminal Classic Settlement and Economies on the Northern Belize Coast", in Sandra L. López Varela and Antonia E. Foias, Geographies of power: understanding the Nature of terminal Classic pottery in the Maya lowlands, BAR International Series 1447, British Archaeological Reports, Oxford, p. 121-133.

Mock Shirley Boteler (ed.)

1998 The sowing and the dawning: Termination, dedication, and transformation in the archaeological and ethnographic record of Mesoamerica, University of New Mexico Press, Albuquerque.

Moholy-Nagy Hatula

2003 The Artifacts of Tikal: Utilitarian Artifacts and Unworked Material. Tikal Report No. 27, Part B, University of Pennsylvania Museum of Archaeology and Anthropology, Philadelphia.

Morales Aguilar Carlos

2012 "Viviendo entre las ruinas: el área central de El Mirador, Petén, Guatemala, durante el periodo Clásico Tardío", in Bárbara Arroyo and Luis Mendez Salinas, XXVI Simposio de Investigaciones Arqueológicas en Guatemala, Museo Nacional de Arqueología y Etnología, Guatemala, p. 773-786.

Moyes Holley, Jaime J. Awe, George A. Brook and James W. Webster

2009 "The Ancient Maya Drought Cult: Late Classic Cave Use In Belize", Latin American Antiquity, 20 (1), p. 175-206.

NaLDa Enrique

2004 Kohunlich Emplazamiento y desarrollo histórico, Colección científica, Serie Arqueología, INAH, México. 
Nalda Enrique and Sandra Balanzario

2014 "El estilo Río Bec visto desde Dzibanché y Kohunlich”, Journal de la Société des américanistes, 100 (2), p. 179-210.

Navarro-Farr Olivia C., David A. Freidel and Ana Lucia Arroyave Prera

2008 "Manipulating Memory in the Wake of Dynastic Decline at El Peru-Waka: Termination Deposits at Abandoned Structure M13-1", in Davis W. Stanton and Aline Magnoni (eds.), Ruins of the Past, The Use and Perception of Abandoned Structures in the Maya Lowlands, University Press of Colorado, Boulder, p. 113-146.

Nelson Ben A., Adrian S. Z. Chase and Michelle Hegmon

2014 "Transformative Relocation in the U.S. Southwest and Mesoamerica", in Arlen Chase and Vernon Scarborough (eds.), The Resilience and Vulnerability of Ancient Landscapes: Transforming Maya Archaeology through IHOPE, AP3A Papers, vol. 24, American Anthropological Association, Arlington, p. 171-182.

Newsome Elizabeth

1996 Precious Stones of Grace: A Theory of the Origin and Meaning of the Classic Maya Stela Cult, Pre-columbian Art Research Institute, San Francisco.

2001 Trees of Paradise and Pillars of the Worlds. The Serial Stelae Cycle of '18-Rabbit-God K', King of Copan, University of Texas Press, Austin.

NondéDÉo Philippe, Marie Charlotte ArNAuld and Dominique Michelet

2013a "Río Bec Settlement Patterns and Local Socio-Political Organization", Ancient Mesoamerica, 24 (2), p. 373-396.

Nondédéo Philippe, Julie Patrois, Alfonso Lacadena, Marie Charlotte Arnauld, Eric TAladoire and Dominique Michelet

2010 "De la autonomía política y cultural de la provincia de Río Bec", Estudios de Cultura Maya 36, p. 37-66.

NondÉDÉo Philippe and Dominique Michelet (eds.)

in press Naachtun-Uxul en el contexto de las tierras bajas mayas y más alla, Centro de Estudios Maya, Mexico.

Nondédéo Philippe, Julie Patrois, Alfonso Lacadena, Marie Charlotte Arnauld, EricTALAdoire and Dominique Michelet

2010 "De la autonomía política y cultural de la provincial de Río Bec", Estudios de Cultura Maya XXXVI, p. 37-66.

Nondédéo Philippe, Alejandro Patiño, Julien Sion, Dominique Michelet and Carlos Morales Aguilar

2013b "Crisis multiples en Naachtun: aprovechadas, superadas e irreversibles", in Marie Charlotte Arnauld and Alain Breton (eds.), Millenary Maya Societies: Past Crises and Resilience. Sociedades mayas milenarias: crisis del pasado y resiliencia, p. 122-147, http://www.mesoweb.com/articles/title.html

O’MANSKY Matt

2014 "Chapter 8-Collapse without drought: warfare, settlement, ecology, and site abandonment in the Middle Pasion Region", in Gyles Iannone (ed.), The Great Maya Droughts in Cultural Context. Case Studies in Resilience and Vulnerability, University Press of Colorado. Boulder, p. 157-176. 
"In the days of my life." Elite activity and interactions in the Maya lowlands

O’MAnsky Matt and Nicholas P. DunNing

2004 "Settlement and Late Classic Political Disintegration in the Petexbatun Region, Guatemala", in Arthur A. Demarest, Prudence M. Rice and Don S. Rice (eds.), The Terminal Classic in the Maya Lowlands: Collapse, Transition, and Transformation, Boulder: University Press of Colorado, p. 83-101.

OKoshi Harada Tsubasa

2000 "Análisis de la organización política territorial de los mayas peninsulares del Postclásico Tardío: Una nueva perspectiva”, in Los Investigadores de la cultura maya, 8, Tomo I, Universidad Autónoma de Campeche, Campeche, p. 29-37.

2010 "La formación de las entidades políticas en las tierras bajas mayas del Posclásico tardío: una nueva perspectiva", in Aurore Monod Becquelin, Alain Breton and Mario H. Ruz (eds.), Figuras mayas de la diversidad, Serie Monografías 10. Universidad Nacional Autónoma de México-Laboratoire d'Ethnologie et de Sociologie Comparative, CNRS-Laboratoire Archéologie des Amériques, CNRS, Mérida, p. 507-536.

2011 "Ch'ibal y cuuchcabal: Una consideración sobre su función en la organización política de los mayas yucatecos del posclásico", in Ana Luisa Izquierdo (ed.), El despliegue del poder: Nuevos estudios sobre la organización política maya, Centro de Estudios Mayas, Instituto de Investigaciones Filológicas, Universidad Nacional Autónoma de México, Mexico, p. 207-224.

2012 "Post-Classic Maya "Barrios" in Yucatan: A Historical Approach", in Marie Charlotte Arnauld, Linda R. Manzanilla and Michael E. Smith (eds.), The Neighborhood as a Social and Spatial Unit in Mesoamerican Cities, University of Arizona Press, Tucson, p. 331-351.

Pascual Soto Arturo and Erik Velásquez García

2012 "Relaciones y Estrategias políticas entre El Tajin y diversas entidades mayas durante el siglo Ix d.C.", in Jaroslaw Zralka, Wieslaw Koszkul and Beata Golinska (eds.), Maya Political Relations and Strategies, Proceedings of the 14th European Maya Conference, Contributions in New World Archaeology, vol. 4, Jagiellonina university and Wayeb, Krakow, p. 205-230.

Pendergast David M.

1985 "Stability through change: Lamanai, Belize, from the ninth to the seventeenth century", in Jeremy A. Sabloff and E. Wyllys Andrews V (eds.), Late Lowland Maya Civilization: Classic to Postclassic, University of New Mexico Press, Albuquerque, p. 223-249.

Ponciano Erick M., Takeshi Inomata and Daniela Triadan

2013 "El abandono de Aguateca, Petén, Guatemala", in Marie Charlotte Arnauld and Alain Breton (eds.), Millenary Maya Societies, Past Crisis and Resilience, Mesoweb Publications, p. 68-72, http://www.mesoweb.com/articles/title.html

Price T. Douglas, Seiichi Nakamura, Shintaro Suzuki, James H. Burton and Vera TiesLer 2014 "New Isotope Data on Maya Mobility and Enclaves at Classic Copan, Honduras", Journal of Anthropological Archaeology, 36, p. 32-47.

Quezada Sergio

2014 Maya Lords and Lordship. The Formation of Colonial Society in Yucatán, 13501600, (translated by Terry Rugeley), University of Oklahoma Press, Norman. 
RATHJE William L.

1970 "Political Implications of Lowland Maya Burials: Methodology and Tentative Hypotheses", World Archaeology, 1 (3), p. 359-374.

Reents-Budet Doris, Stanley Guenter, Ronald L. Bishop and James Blackman

2012 "Indentity and interaction. Ceramic Styles and Social History of the Ik'Polity, Guatemala", in Antonia E. Foias and Kitty F. Emery (eds.), Motul de San José. Politics, History and Economy in a Classic Maya Polity, University Press of Florida, Gainesville, p. 67-93.

Restall Matthew

1997 The Maya world: Yucatec culture and society, 1550-1850, Stanford University Press, Stanford.

RicE Prudence M.

1987 "Economic Change in the Lowland Maya Late Classic Period", in Elizabeth M. Brumfield and Timothy K. Earle (eds.), Specialization, Exchange And Complex Societies, Cambridge University Press, Cambridge, p. 76-85.

2004 Maya Political Science. Time, Astronomy, and the Cosmos. University of Texas press, Austin.

Rice Prudence M. and Donald W. Forsyth

2004 "Terminal Classic-Period Lowland Ceramics", in Arthur A. Demarest, Prudence M. Rice and Don S. Rice (eds.), The Terminal Classic in the Maya Lowlands: Collapse, Transition, and Transformation, University Press of Colorado, Boulder, p. 28-59.

Rice Don S. and Prudence M. Rice

1990 "Population Size and Population Change in the Central Peten Lakes Region, Guatemala", in T. Patrick Culbert and Don S. Rice (eds.), Precolumbian Population History in the Maya Lowlands, University of New Mexico Press, Albuquerque, p. 1-36.

Rice Don S., Prudence M. Rice and T. Pugh

1998 "Settlement Continuity and Change in the Central Peten Lakes Region: The Case of Zacpeten", in Andrés Ciudad Ruiz et al. (eds.), Anatomia de una civilización, Sociedad Española de Estudios Mayas, Madrid, p. 207-252.

Rice Prudence M. and Don S. Rice

2004 "Late Classic to Postclassic Transformation in the Petén Lakes region", in Arthur A. Demarest, Prudence M. Rice and Don S. Rice (eds.), The Terminal Classic in the Maya Lowlands: Collapse, Transition, and Transformation, University Press of Colorado, Boulder, p. 125-139.

2007 "The Terminal Classic-to-Early Postclassic transition in the Central Petén Lakes region", in Cristina Vidal Lorenzo and Gaspar Muñoz Cosme (eds.), La Blanca y su entorno, Cuadernos de Arquitectura y arqueología maya, Ministerio de Cultura, Valencia, p. 145-159.

RingLE William M.

2004 "The Political Organization of Chichen Itza", Ancient Mesoamerica, 15, p. 167-218.

Ringle William M. and George J. Bey III

2004 "The Decline of the East: The Classic to Postclassic Transition at Ek Balam", in Arthur A. Demarest, Prudence M. Rice and Don. S. Rice (eds.), The Terminal 
"In the days of my life." Elite activity and interactions in the Maya lowlands

Classic in the Maya Lowlands: Collapse, Transition, and Transformation, University of Colorado Press, Boulder, p. 485-516.

2009 "The face of the Itzas", in William L. Fash and Leonardo López Luján, The Art of Urbanism: How Mesoamerican Kingdoms Represented Themselves in Architecture and Imagery, Dumbarton Oaks Research, Washington, p. 329-383.

Ringle William M., T. Gallareta Negron and George J. Bey III

1998 "The return of Quetzalcoatl: Evidence for the spread of a world religion during the Epiclassic period", Ancient Mesoamerica, 9, p. 183-232.

Roys Ralph L.

1940 "Personal Names of the Maya of Yucatan", Contributions to American Anthropology and History 6, Carnegie Institution of Washington, Washington, p. 31-48.

SABLoff Jeremy A.

1973 "Continuity and Disruption during Terminal Late Classic Times at Seibal: Ceramic and Other Evidence", in T. Patrick Culbert (ed.), The Classic Maya Collapse, University of New Mexico Press, Albuquerque, p. 107-31.

1975 Excavations at Seibal. Ceramics. PMAE Memoires 13-2. Harvard University, Cambridge, MA.

1986 "Interaction among Classic Maya polities: a preliminary examination", in Colin Renfrew and J. F. Cherry (eds.), Peer Polity Interaction and Sociopolitical Change, Cambridge University Press, New York, p. 109-116.

SCHELE Linda and Peter MATHEwS

1998 The Code of Kings. The Language of Seven Sacred Maya Temples and Tombs, Scribner, New York.

SCHerer Andrew K. and Charles Golden

2014 "Chapter 10-Water in the West: chronology and collapse of the classic Maya river kingdoms", in Gyles Iannone, The Great Maya Droughts in Cultural Context. Case Studies in Resilience and Vulnerability, University Press of Colorado. Boulder, p. 207-229.

SCHOLLMEYeR Karen Gust

2011 "Large game, agricultural land, and settlement pattern change in the eastern Mimbres area, southwest New Mexico", Journal of Anthropological Archaeology 30, p. 402-415.

SHARER Robert J.

1994 The Ancient Maya (Fifth edition), Stanford University Press, Stanford.

SiON Julien

2014 Crisis y Prosperidad. El Clásico Terminal en Naachtun. XXVIII Simposio de Arqueología en Guatemala, Guatemala (in press).

2016 La caractérisation socio-économique des élites mayas au Classique terminal (830-950 apr. J.C.): le Groupe B-Sud de Naachtun (Guatemala). Thèse de doctorat, Université de Paris 1 Panthéon-Sorbonne, Paris.

in press “¿Qué paso en Naachtun durante el Clásico Terminal? Un “apogeo” analizado en una perspectiva regional", in Philippe Nondédéo and Dominique Michelet (dir.), Naachtun-Uxul en el contexto de las tierras bajas mayas y mas alla, Centros de Estudios Maya, Mexico. 
SMITH Ledyard A.

1982 Excavations at Seibal, Department of Peten, Guatemala, Cambridge, Memoirs of the Peabody Museum of Archaeology and Ethnology, vol. 15, no. 1, Harvard University.

Sмiтн Michael E.

1992 "Braudel's temporal rhythms and chronology theory in archaeology", in Arthur B. Knapp (ed.), Archaeology, Annales, and Ethnohistory, Cambridge University Press, Cambridge, p. 23-34.

Stanton Travis W., M. Kathryn Brown and Jonathan B. Pagliaro

2008 "Garbage of the Gods? Squatters, refuse, disposal, and termination rituals among the Ancient Maya", Latin American Antiquity, 19 (3), p. 227-247.

Stanton Travis W. and Thomas Gallareta Negron

2001 "Warfare, ceramic economy, and the Itza. A reconsideration of the Itza Polity in ancient Yucatán", Ancient Mesoamerica, 12 (2), p. 229-245.

Stuart David

1993 "Historical inscriptions and the Maya Collapse", in Jeremy A. Sabloff and John S. Henderson Lowland maya Civilization in the Eight Century AD, Dumbarton Oaks, Washington, p. 321-354.

1996 "Kings of Stone: A Consideration of Stelae in Ancient Maya Riitual and representation", RES, 29/30, p. 148-171.

2000 "The Arrival of Strangers", in David Carrasco, Lindsay Jones and John S. Sessions Mesoamerica's Classic Heritage. From Teotihuacan to the Aztecs, University of Colorado Press, Boulder, p. 465-513.

2011 The Order of Days: The Maya World and the Truth about 2012, Harmony Books, New York.

Stuart David and Stephen Houston

1994 Classic Maya Place names. Studies in Precolumbian Art and Archaeology 33, Dumbarton Oaks, Washington.

Suasnávar José, Alan Robinson, Heidy Quezada, Oscar Ixpatá, Guillermo VÁsquez and Patricia IXCOT

2007 "Investigación antropológico-forense de La Aguada Sur del sitio arqueológico Cancuen, Operación 42", Report on the Proyecto Arqueológico Cancuen, Guatemala. Fundación de Antropología Forense de Guatemala, Guatemala City.

Taladoire Eric, Sara Dzul and Mélanie Forné

2013 "Chronology of the Río Bec Settlement and Architecture", Ancient Mesoamerica, 24 (2), p. 353-372.

Ting Carmen, Elizabeth Graham and Marcos Martinón-TORRES

2014 "Molding the 'collapse': Technological analysis of the Terminal Classic molded-carved vases from Altun Ha, Belize", in Marcos Martinón-Torres (ed.), Craft and science: International perspectives on archaeological ceramics. Bloomsbury Qatar Foundation, Doha, Qatar, http://dx.doi.

TOKOvinine Alexandre and Marc ZENDER

2012 "Lords of Windy Water: The Royal Court of Motul de San José in Classic Maya Inscriptions", in Antonia E. Foias and Kitty F. Emery Motul de San 
"In the days of my life." Elite activity and interactions in the Maya lowlands

José. Politics, History and Economy in a Classic Maya Polity, University Press of Florida, Gainesville, p. 30-66.

TOURTELLOT Gair

1970 “The Peripheries of Seibal: An Interim Report”, in William R. Bullard Jr. (ed.), Monographs and Papers in Maya Archaeology, Papers of the Peabody Museum of Archaeology and Ethnology, vol. 61, p. 405-419.

Tourtellot Gair and Jason J. GonZÁLEZ

2004 "The last Hurrah: Continuity and transformation at Seibal", in Arthur A., Demarest, Prudence M. Rice and Don. S. Rice (eds.), The Terminal Classic in the Maya Lowlands: Collapse, Transition, and Transformation, University of Colorado Press, Boulder, p. 60-82.

Tozzer Alfred M.

1957 Chichen Itza and its Cenote of Sacrifice. Memoirs of the Peabody Museum, vol. 11, vol. 12, Harvard University, Cambridge.

TRIADAn Daniela

2012 "El resurgimiento político de Ceibal en el Clásico Terminal” in Maria Elena Vega Villalobos and Lynneth S. Lowe, La cuenca del Río de la Pasión: estudios de arqueología y epigrafía maya, UNAM, Mexico, p. 155-170.

Turner II Billie L. and Jeremy A. SABlofF

2012 "Classic Period Collapse of the Central Maya Lowlands: Insights about human-environment relationships for sustainability", Proceedings of the National Academy of Sciences, August 28, 109 (35), p. 13908-13914.

VALDÉs GómEZ Juan Antonio

2005 "El periodo Clásico terminal y el ocaso de la cultura maya en Petén, Guatemala", in Gaspar Muñoz Cosme and Cristina Vidal Lorenzo (eds.), La Blanca, arqueología y desarrollo, Ministerio de Cultura,Valencia, p. 53-64.

VALDÉs Juan Antonio and Federico FAHSEN

2004 "Disaster in sight: The Terminal Classic at Tikal and Uaxactun", in Arthur A., Demarest, Prudence M. Rice and Don. S. Rice (eds.), The Terminal Classic in the Maya Lowlands: Collapse, Transition, and Transformation, University of Colorado Press, Boulder p. 140-161.

Vega Villalobos María Elena

2011 "Los señores de Ceibal. Un estudio de los textos jeroglíficos del Clásico Tardío", Estudios Mesoamericanos Nueva Epoca 10, p. 5-23.

Volta Beniamino and Geoffrey E. BRASWELL

2014 "Alternative Narratives and Missing Data: Refining the Chronology of Chichen Itza", in Geoffrey E. Braswell (ed.), The Maya and Their Central American Neighbors: Settlement patterns, Architecture, Hieroglyphic Texts, and Ceramics, Routledge, New York, p. 356-402.

WeBSTER David

2002 The fall of the Ancient Maya. Thames and Hudson, London.

2014 "Maya drought and niche inheritance", in Gyles Iannone (ed.), The Great Maya Droughts in Cultural Context. Case Studies in Resilience and Vulnerability, University Press of Colorado, Boulder, p. 333-349. 
Webster James W., George A. Brook, L. Bruce Railsback, Hai Cheng, R. Lawrence Edwards, Clark Alexander and Philip P. Reeder

2007 "Stalagmite Evidence from Belize Indicating Significant Droughts at the Time of Preclassic Abandonment, the Maya Hiatus, and the Classic Maya Collapse", Palaeogeography, Palaeoclimatology, Palaeoecology, 250, p. 1-17.

Wright Leslie E.

2012 "Immigration to Tikal, Guatemala: Evidence from stable strontium and oxygen isotopes", Journal of Anthropological Archaeology, 31, p. 334-352.

YAEGER Jason

2013 "Household archaeology and population mobility in the Mopan River valley, Belize", Paper presented at the symposium Population mobility in the hinterland of Maya cities, 78th Society for American Archaeology Annual Meeting, Honolulu.

YAEGER Jason and David A. Hodell

2008 "The Collapse of Maya Civilization: Assessing the Interaction of Culture, Climate, and the Environment", in Dan H. Sandweiss and Jeff Quilter (eds.), El Nino, Catastrophism, and Culture Change in Ancient America, Harvard University Press, Cambridge, p. 187-242.

ZARo Gregory and Brett A. Houk

2012 "The Growth and Decline of the Ancient Maya City of La Milpa, Belize: New Data and New Perspectives from the Southern Plazas", Ancient Mesoamerica, 23 (1), p. 143-159.

ZENDER Mark

2002 "A Note on the Inscription of Ixtutz Stela 4", The PARI Journal, 2 (4)/3 (1), p. 17-27, Electronic edition. Mesoweb: http:/www.mesoweb.com/articles/ title.html

ŹraŁKA Jaroslaw

2008 Terminal Classic Occupation in the Maya Sites Located in the Area of Triangulo Park, Peten, Guatemala, Prace Archeologicze, no. 62, Monographs Jagiellonian University Press, Krakow.

ŹraŁkA Jarosław and Bernard Hermes

2012 "Great development in troubled times: The Terminal Classic at the Maya Site of Nakum, Petén, Guatemala”, Ancient Mesoamerica, 23, p. 161-187. 